\title{
Microbial Alterations and Risk Factors of Breast Cancer: Connections and Mechanistic Insights
}

\author{
Sheetal Parida and Dipali Sharma * \\ Department of Oncology, Johns Hopkins University School of Medicine and the Sidney Kimmel Comprehensive \\ Cancer Center at Johns Hopkins, Baltimore, MD 21218, USA; sparida1@jhu.edu \\ * Correspondence: dsharma7@jhmi.edu
}

Received: 3 March 2020; Accepted: 23 April 2020; Published: 28 April 2020

\begin{abstract}
Breast cancer-related mortality remains high worldwide, despite tremendous advances in diagnostics and therapeutics; hence, the quest for better strategies for disease management, as well as the identification of modifiable risk factors, continues. With recent leaps in genomic technologies, microbiota have emerged as major players in most cancers, including breast cancer. Interestingly, microbial alterations have been observed with some of the established risk factors of breast cancer, such as obesity, aging and periodontal disease. Higher levels of estrogen, a risk factor for breast cancer that cross-talks with other risk factors such as alcohol intake, obesity, parity, breastfeeding, early menarche and late menopause, are also modulated by microbial dysbiosis. In this review, we discuss the association between known breast cancer risk factors and altered microbiota. An important question related to microbial dysbiosis and cancer is the underlying mechanisms by which alterations in microbiota can support cancer progression. To this end, we review the involvement of microbial metabolites as effector molecules, the modulation of the metabolism of xenobiotics, the induction of systemic immune modulation, and altered responses to therapy owing to microbial dysbiosis. Given the association of breast cancer risk factors with microbial dysbiosis and the multitude of mechanisms altered by dysbiotic microbiota, an impaired microbiome is, in itself, an important risk factor.
\end{abstract}

Keywords: microbiota; microbiome; breast cancer; obesity; aging; estrogen; periodontal disease; xenobiotics; microbial metabolites

\section{Introduction}

The efforts of human microbiome projects and advances in culture-independent omics technologies have revolutionized our understanding of the relationship between humans and the commensals residing within our bodies. The human microbiome project was initiated in 2008, with the objective of understanding human beings as super-organisms, comprising human and over 100 trillion non-human microbial cells, whose collective genes exceed human genes by 150 times [1]. Trillions of microbes have co-evolved with humans, occupying different niches within the human body by supporting and augmenting metabolic processes for the sustenance of life; the normal gut microbiota alone account for 3.3 million genes [2]. It is imperative to investigate the interaction between the microbiome and the human genome, as microbiota can substantially manipulate the normal biological functions of the human body and have been found to influence the likelihood of major non-infectious diseases including diabetes, autoimmune diseases, inflammatory bowel disease (IBD) and various organ specific cancers. The human microbiome project primarily aimed to characterize the microbiota of five body sites including those of the skin, mouth, nose, colon and vagina. Intriguingly, a decade of research has also revealed the presence of unique and distinct microbial communities, even in organs previously considered "sterile or devoid of microbes" including the lungs [3-5], pancreas [6-8], prostate [9-11] and breasts $[1,12]$. An imbalance in the composition of these microbial communities is capable of 
supporting a carcinogenic transformation in these sites by altering immunological functions [13-20], energy harvest efficiency [21,22], the synthesis of small metabolites, which could function as signaling molecules [23-26], and the regulation of circulating levels of steroid hormones in the body [27]. Some of the known microbial species are capable of influencing DNA damage, genomic instability, mutations and epigenetic modifications [28,29]. It is interesting to note that the microbiota can affect Hanahan and Weinberg's widely accepted hallmarks of cancer [30]. Moreover, several risk factors associated with breast cancer have a two-way relationship with microbiota, as they are modulated by microbial dysbiosis and can modulate microbiota. In this article, we review the relationship between several important breast cancer risk factors and microbial dysbiosis and also discuss the ways in which the human microbiota may influence breast cancer progression and responses to treatment.

Search strategy and selection criteria: A PubMed search was performed using various keywords, including cancer, breast cancer, microbiota, microbiome, breast cancer risk factors, cancer immunoregulation and microbial metabolites, in order to acquire original papers, population-based studies and review articles in English. All papers relevant to the importance of microbiota in breast cancer growth, progression, aggressiveness, metastasis and disease outcome were included. Papers and trials not directly related to the role of microbiota in breast cancer in general were excluded. All papers referred to are cited.

\section{Microbiota in Breast Cancer}

The connection between microbes and breast cancer was initially put forth by epidemiological studies querying the impact of antibiotic usage on breast cancer. Antibiotics can modulate the intestinal flora, resulting in the reduced metabolism of phytochemicals that may, in turn, lower their cancer-protective effects. On the other hand, a decrease in estrogen metabolism via the intestinal flora can lower circulating estrogen, lowering the risk of developing of estrogen receptor (ER)-positive breast cancer [31,32]. A case control study queried the use of antibiotics in 2266 women with breast cancer and 7953 healthy controls and inferred that antibiotic use was associated with a higher breast cancer incidence and the aggressiveness of the disease. However, a causal relationship with antibiotics and breast cancer was not determined [33]. A cohort of 2.1 million women with a follow-up of nine years showed a weak causal relationship between antibiotic use and breast cancer [34]. A weak association was also found between antibiotic use and higher tumor grade [35]. In a large study, including 3099 women with breast cancer and 12,396 matched controls, a non-causal dose-dependent relationship between antibiotic usage and increased breast cancer risk was noted [36]. A meta-analysis of five studies comprising of 13,069 breast cancer cases and 73,920 controls showed a slight increase in breast cancer risk in women who had ever used antibiotics vs. the never-used antibiotics group [37]. Frequent antibiotic use ( $\geq 4$ antibiotics in one year) showed a modest elevated risk for second breast cancer events in a large study involving 4216 women [38]. The modulation of microbiota with antibiotic use has recently been associated with therapeutic outcomes in cancer patients undergoing immunotherapy regimens (reviewed in [39]). Collectively, these studies indicate that antibiotic usage may modulate breast cancer risk, although the establishment of a causal relationship requires additional studies, and the mechanistic links may be manifold, ranging from microbiota alterations to underlying disease conditions. Nonetheless, these epidemiological studies have sparked investigations to decipher the links between microbiota and breast cancer in a more directed manner.

Multiple recent studies have investigated the breast microbiota in cohorts comprising healthy volunteers, women with benign or malignant breast cancer and breast cancer survivors $[25,26,40-44]$. A study including 81 women from Canada and Ireland collected breast tissue from various locations within the breast, including areas close to the nipple as well as the chest wall and found the presence of bacteria in all locations. Diverse bacterial communities were present in breasts with Shannon's diversity indices of $0.8-5.2$, with an average of 3.6, which was quite comparable to oral and gut samples with diversity indices between 3.9 and 6.5. Organisms associated with pathogenesis in other organs, including Streptococcus agalactiae, Enterobacteriaceae and Pseudomonas, were also detected in 
breast tissue [40]. An examination of breast tumors and adjacent normal tissue from the same patient showed unique microbial communities associated with tumors as well as normal samples. Breast tumors had lower bacterial DNA loads in comparison to normal breast tissue and this correlated inversely with increasing tumor stages. Interestingly, unique microbiota alterations were noted in tumor and normal tissues, with the enrichment of Sphingomonas yanoikuyae in normal tissue and Methylobacterium radiotolerans in tumor tissue [45]. Both studies noted an abundance of members of Proteobacteria phylum in breast tissue which was distinct from other body sites where this phylum represents a small portion of the total bacterial load [40,45]. Analyses of paired breast tissue and breast skin samples showed the presence of distinct microbiota in breast tissue, especially the rare bacterial lineages [42]. An interesting question with respect to breast cancer microbiota is whether distinct microbiota alterations are associated with benign or malignant breast cancer. A comparison between adjacent normal breast tissue acquired from women with benign breast disease or with invasive breast cancer revealed significant differences in their microbiota. Breast tissue from women with invasive breast cancer revealed an abundance of some lowly abundant genera, including Atopobium, Fusobacterium, Lactobacillus, Hydrogenophaga and Gluconacetobacter [42]. The enrichment of specific genus-level taxa in adjacent normal breast tissue associated with malignant disease puts forth the notion that distinct microbiota alterations may be important for disease progression. Studies by Urbaniak et al. and Hieken et al. found a similar order of abundance of phyla-Bacteroidetes, Actinobacteria, Firmicutes and Proteobacteria in ascending order $[40,42]$. Since the breast ductal tree has 6-8 openings at the nipple area, which may allow microbes from the environment to inhabit the ductal system of the breast, it is plausible that nipple aspirate fluid contains microbes and that this may correlate with breast cancer. Indeed, the examination of nipple aspirate fluid (NAF) from women with a history of breast cancer or healthy volunteers showed that NAF from the breast cancer group was enriched with the genus Alistipes, whereas NAF from healthy volunteers contained an abundance of an unclassified genus from the Sphingomonadaceae family [41]. These studies showed the presence of distinct microbiota in breast tissue and highlighted the differences between study groups. Our group uniformly re-analyzed the raw data from the abovementioned studies in an attempt to find common candidate microbes across the data sets that could account for breast carcinoma [46]. Differences in community composition across data sets can be attributed to ethnicities, dietary habits, geography, lactation status, the method of sample collection and platform of sequencing and data analysis. The majority of breast microbiota are composed of Firmicutes, Bacteroides and Proteobacteria. Some interesting patterns were observed in microbiota composition, e.g., in one data set, $2.2 \%$ of the total bacterial count in the healthy breast tissue was Lactobacillus, whereas in cancerous tissue, it formed only $1.4 \%$ of the total bacterial count. It is noteworthy that Lactobacilli have been shown to be protective against breast cancer. Some microbes with known cancer-promoting functions were found to be enriched in breast tumors, e.g., breast cancer tissue overrepresented Bacillus cereus, a microbe known to metabolize progesterone and testosterone to 5 -alpha-3,20-dione $(5 \alpha \mathrm{P})$ and to induce the proliferation of breast cancer cells in vitro. Two important microbes, E coli and Staphylococcus epidermidis, known to induce double-stranded DNA breaks in HeLa cells, were found to be enriched in cancerous breast tissue. Breast cancer tissue samples were also found to harbor higher levels of Fusobacterium sp. Notably, Fusobacterium is a well-known cancer-promoting pathogen in colorectal cancer CRC [46]. Collectively, these studies not only demonstrate the presence of breast microbiota, but also show the association of distinct microbiota with breast cancer.

\section{Risk Factors Associated with Breast Cancer}

Broadly classified as modifiable and non-modifiable, several risk factors have been associated with breast cancer. Non-modifiable risk factors include gender, age, race, genetic susceptibility, exposure to radiation, family or personal history of breast cancer, high breast density, benign breast disease, early menarche, late menopause and steroid hormone levels, while obesity, a lack of physical activity, alcohol, oral contraceptive use/hormone replacement therapy, parity, breastfeeding, and periodontal disease are considered modifiable risk factors. Women are at a higher risk of developing breast cancer 
(one in eight women will develop breast cancer in their lifetime) in comparison to men (one in 883 men will develop breast cancer in their lifetime) $[47,48]$. Breast cancer risk increases with age and older women show a higher incidence of breast cancer. While the total number of breast cancer incidences is higher in white women, black women are at a higher risk of developing triple-negative breast cancer, and a more aggressive disease [49]. Several tools have been developed to assess the risk of developing breast cancer in women. Gail 1 included multiple risk factors, such as age at menarche, age, age at live birth of first child, family history of breast cancer, number of breast biopsies, number of biopsies showing atypical hyperplasia, and race/ethnicity. Later, it was modified to include the history of affected first degree family members (Gail 2), occupational physical activity level, education, body mass index (BMI), alcohol consumption status, leisure activities (h/wk) (absolute risk prediction model) and to include black women (the Women's Contraceptive and Reproductive Experiences or CARE), and US Hispanic women for better risk prediction [50-54]. Breast and Ovarian Analysis of Disease Incidence and Carrier Estimation Algorithm (BRCA) probability tools (Ontario Family History Assessment Tool, BRCAPRO, Myriad I and II, and Manchester scoring system) were also developed to account for genetic risk factors [50,54-56]. Multiple risk factors have been defined for breast cancer incidence, but it is important to note that a large number of $(\sim 70 \%)$ women who develop breast cancer in their lifetime do not carry established risk factors. There is an immediate need to look beyond the usual suspects and incorporate newer aspects, such as microbial alterations. Recent studies have shown an association of some of the breast cancer risk factors, namely obesity, aging, estrogen exposure (modulated by early menarche and late menopause) and periodontal disease, with microbiota. Hence, in this section, we will review the microbial alterations related to obesity, aging, high estrogen levels and periodontal disease.

\subsection{Obesity, Breast Cancer and Microbiota}

Obesity is an important risk factor for breast cancer, not only because of its physiological effects on an individual, but also due to its steadily increasing worldwide prevalence. Approximately, $13 \%$ of the world population is obese and $36 \%$ adults in USA are obese [57]. Multiple studies and meta-analyses have reported a positive correlation between breast cancer and obesity [57-67]. Though the magnitude of its impact varies among studies, a strong positive correlation has been observed between high body mass index (BMI) and hormone receptor-positive breast cancer risk in postmenopausal women [57], while studies focusing on premenopausal women have shown a positive correlation, as well as a negative correlation, between high BMI and overall breast cancer risk $[57,58,68-70]$. In most studies, the risk of triple-negative breast cancer (TNBC) and inflammatory breast cancer (IBC) is positively associated with a higher BMI. In a case-control study with 68 IBC patients, IBC risk was 4 fold higher with BMI > 26.65 [71]. IBC risk also increases between three and fivefold with obesity in postmenopausal women [71]. Overall, a poor prognosis and higher mortality have been observed in obese breast cancer patients, irrespective of menopausal status, breast cancer subtype and ethnicity (reviewed in [57]).

With the growing appreciation of the role of gut microbiota in metabolic processes, efforts are underway to decipher the interplay between the gut ecosystem, diet and obesity [24,72-87]. The idea was first put forth by immunologist Elie Metchnikoff in his disquisition "Essais optimistes", where he proposed that the products of microbial fermentation in the gut could cause systemic inflammation and obesity [80]. Though most of the studies on human microbiota have focused on its immune-mediated roles, a number of physiological functions independent of immune responses have also emerged. For example, many bacterial metabolites capable of inducing cellular signaling pathways have gained attention $[15,23,73,88-106]$. The descriptive profiling of gut microbiota has revealed a correlation between obesity and microbial classes in both humans and rodents $[77,79,80,85,87,103,107-109]$. In the obese state, an increase in the abundance of Firmicutes and a decrease in Bacteroidetes has been observed in most studies $[77,79,87,108,110]$, except a few that report opposite results $[21,111,112]$. Within phylum Firmicutes, Mollicutes are most abundant in the obese state [87]. Most Firmicutes encode enzymes involved in lipid and carbohydrate metabolism. While some studies noted an 
increase in the levels of Actinobacteria and a decrease in Bacteroidetes, with no change in Firmicutes, others have seen an increase in Lactobacilli (phylum Firmicutes) in the obese state [77,111]. Again, among Lactobacillus species, a higher occurrence of Lactobacillus reuteri and lower levels of Lactobacillus casei/paracasei and Lactobacillus plantarum have been associated with obesity [113]. Interestingly, a similar increase in Firmicutes to Bacteroides ratio has been observed in breast cancer compared to normal breasts $[45,46]$ and malignant breast cancer compared to benign breast disease as well $[42,46]$. In obese women, reduced Bacteroides and increased Staphylococcus, Enterobacteriaceae and E. coli has been observed with high BMIs [77]. The overrepresentation of Staphylococcus, Enterobacteriaceae and E. coli has also been observed in breast cancer tissue [46]. Overall, many microbial families and species enriched in the obese state are similar to those observed in breast cancer samples compared to normal breasts, suggesting a microbial link between obesity and breast cancer risk [46]. Though a direct association is yet to be found, obesity has also been shown to be influenced by certain groups of microbial commensals, which could be associated with long-term dietary choices $[24,75,111,112,114]$.

Interestingly, it has been demonstrated that adiposity in humans as well as mice could be altered by fecal transplants and/or inoculation with specific bacteria and, moreover, that humanized germ-free mice mirror the donor's adiposity [85]. While some studies have shown the extensive remodeling of microbial ecology being causally associated with obese phenotypes, suggesting the role of specific microorganisms, others highlight the importance of species-independent genes or pathways with common molecular functions $[80,85]$. The strongest evidence supporting a microbial association with obesity comes from the fact that germ-free mice demonstrate lower body fat mass despite increased food consumption compared to conventionalized mice [80,85]. Higher adiposity has also been observed in conventional mice on autoclaved normal diets, as well as high fat diets, compared to germ-free mice $[80,85]$. Intriguingly, colonizing germ-free mice with a combination of Bacteroides thetaiotaomicron and Methanobrevibacter smithii results in an increase in weight gain and adiposity $[77,80,113]$. The microbiota's contribution to adiposity is, indeed, multifold and various hypotheses, including increased energy harvest and enhanced metabolism, have been put forward to explain the microbiota-obesity connection.

The enhanced energy harvest efficiency of an obese microbiota $[77,87]$ occurs due to a culmination of multiple interdependent processes, including the microbial fermentation of otherwise indigestible polysaccharides, the absorption of monosaccharides and the production of short-chain fatty acids (SCFAs) such as butyrate, propionate and acetate [76,78,101,106,115] (Figure 1). SCFAs undergo hepatic conversion to form complex lipids and microbiome-mediated gene regulation promotes the storage of these complex lipids in the adipocytes. Mice deficient in G protein coupled receptor GPR41, a cell surface receptor for a variety of SCFAs [73], were found to be protected from obesity when lacking a normal gut microbiota but not in the presence of a conventional microbiota [24]. Microbiota-induced YY peptide expression also alters food intake [74]. Alternatively, this can be due to defects in normal leptin production driven by SCFAs in the adipose tissue [116], since GRP41-deficient mice do not produce normal levels of leptin [24]. Another proposed mechanism mediating obesity protection in germ-free mice is the lack of expression of fiaf/angptl4 in the intestinal lumen, which negatively regulates lipoprotein lipase, the enzyme responsible for maintaining lipid uptake into tissue [117]. Some classes, e.g., Firmicutes, have been described to be involved in fat metabolism and weight regulation $[24,114]$ but to fully understand the association, it is necessary to conduct studies on germ-free mice and compare them with mono-colonized mice, followed by an evaluation of the underlying metabolic pathways. Experimental clarification about the extent to which this increased energy harvest can influence adiposity by overcoming the body's homeostatic system has been provided by the elegant studies of Gordon and colleagues [118]. They have demonstrated that gut microbiota modification by fecal transplant can result in a 60\% increase in total body adipose mass within 10 to 14 days in 8- to 10 -week-old mice [118]; this corresponds to 4.7 to 7 years in a 20-year-old human being. Such fat gain is sufficient to transform a lean individual into a morbidly obese individual in short time, completely dysregulating the hormonal balance of the body. Gordon and colleagues colonized germ-free mice with 
Bacteroides thetaiotaomicron, which led them to the understanding that the gut microbiome modulates the gene expression required for vasculogenesis and angiogenesis, in addition to nutrient absorption, immune regulation and xenobiotic metabolism $[119,120]$. A multitude of interesting observations have put forth the relevance of microbial dysbiosis in the obesity-breast cancer axis. As such, obesity is one of the most important risk factors in breast cancer. The identification of specific taxa involved in the modulation of bodily fats can help develop a strategy to therapeutically prevent and treat obesity, thus reducing breast cancer risk. Clinical studies are investigating the microbiome connection to breast cancer aggravated by obesity [121]. One candidate organism that has gained importance in the recent past is Akkermansia muciniphila, which in under-represented in the gut of obese individuals. The loss of $A$. muciniphila causes the thinning of the mucus lining of the intestines, thus allowing lipopolysaccharide LPS and other endotoxins to leak into the circulation, causing chronic inflammation. A clinical trial examining A. muciniphila in obese breast cancer patients aged 60 to 70 years observed an association between BMI and A. muciniphila levels in early stages of breast cancer. Alpha diversity positively correlated with $A$. muciniphila levels [122,123]. Species richness, as well as fat mass, positively correlated with critical cytokine IL6 [123], suggesting that the gut microbial population is altered in the obese state, which can lead to chronic inflammation, which can worsen breast cancer outcomes.

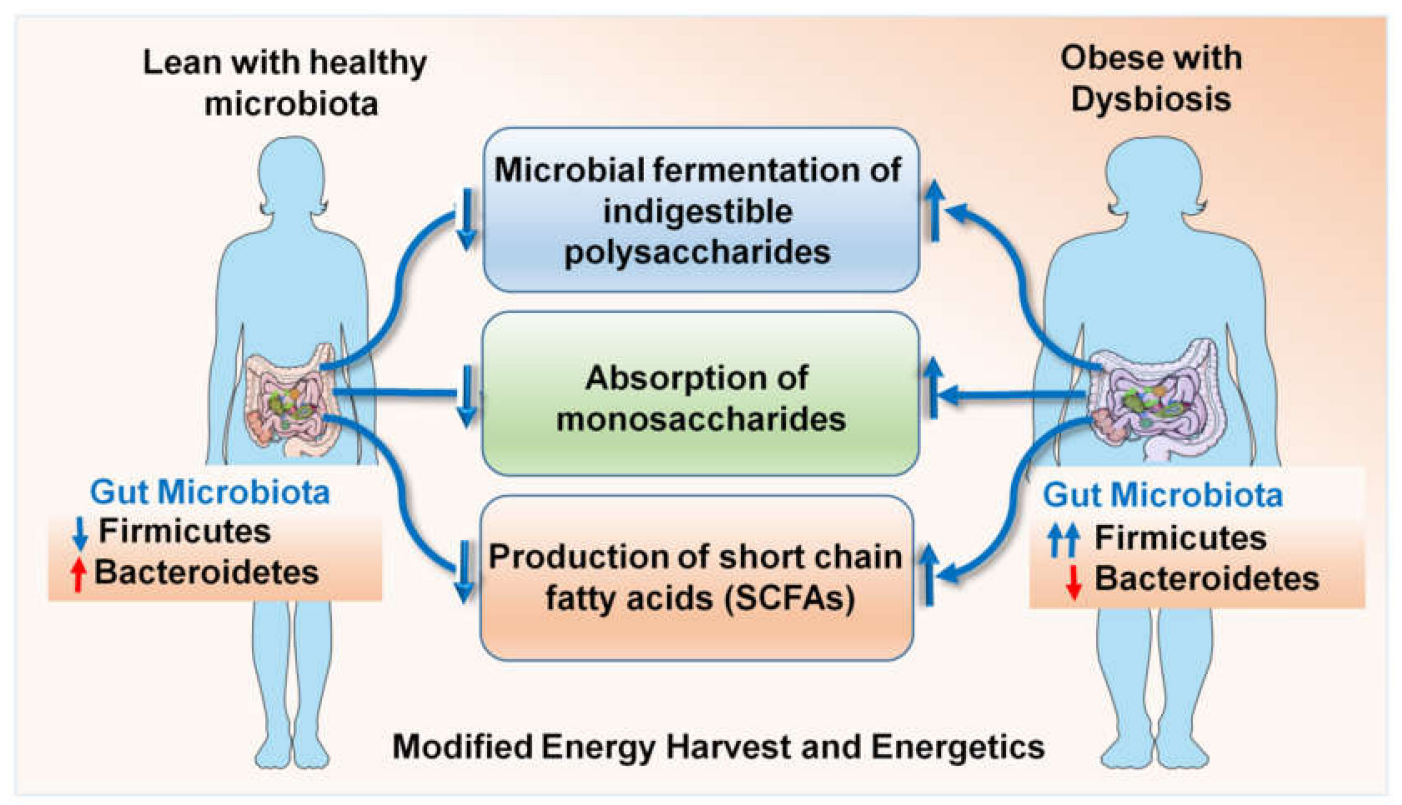

Figure 1. Microbial dysbiosis in obese states contributes to dysregulated energy harvest and energetics.

\subsection{Aging, Breast Cancer and Microbiota}

The risk of being diagnosed with breast cancer increases with age, which is one of the non-modifiable factors. Breast cancer diagnosed in women over age 50 accounts for $\sim 80 \%$ of all breast cancers and an exponential rise in invasive breast cancer and ductal carcinoma in situ has been observed up until menopause (age 50). The 10-year probability of invasive breast cancer incidence is $1.5 \%$ at age 40 , increasing to $3 \%$ and $4 \%$ by age 50 and 70 respectively, leading to an overall risk of $13.2 \%$ or one in eight women. All breast cancer subtypes exhibit similar increases in age-specific incidence rates in premenopausal settings, while only ER-positive/PR-positive and ER-positive/PR-negative subtypes maintain increased age-specific incidence rates in postmenopausal settings [124]. Cellular and molecular changes associated with aging may render normal breast epithelial cells susceptible to malignant transformation [125,126]. Microbiome changes present another key aspect of the cancer-aging relationship, as the human microbiota is dynamic and it continuously evolves with age and exposure to environmental factors. An infant gut is mainly colonized with Bifidobacterium infantis and some related species, the only organisms capable of digesting the complex indigestible oligosaccharides of mother's 
milk, which are indispensable for the baby's energy requirements $[127,128]$. These bacteria also prevent the colonization of pathogens, since infants do not have a well-developed immune system, and set in motion the first immune response in a human body. As humans age, the microbiota co-evolves depending on dietary habits, drug usage and environmental factors. Firmicutes and Bacteroidetes are the major taxa present in the human gut and their relative ratio has been implicated in health and disease. Furet and colleagues analyzed the F/B ratio in infants, the adult and elderly population, and found that the F/B ratio was significantly higher in adults, but showed a drop in the elderly, showing no significant difference from infants [129]. Interestingly, the levels of genus Bifidobacterium was similar in adults and the elderly [129], suggesting that, although there is a depletion of microbial diversity in the elderly, which can slow down and prevent metabolism and the degradation of xenobiotics in a similar manner to infants, the elderly do not gain a protective immune environment as infants conferred by probiotics like Bifidobacterium do. Bifidobacterium is known to inhibit breast cancer progression [130] and has been proposed as a therapeutic strategy [130-132]. Although the microbial control of aging has been widely appreciated lately [133-135], it actually started with Elie Metchnikoff in the early 1900s. Aging has been found to be associated with a decline in the saccharolytic bacterial population and increased proteolytic bacteria in the gut [136]. Consequently, SCFAs in circulation are greatly reduced, impairing immune modulation. Aging sets in motion a process of chronic inflammation, increasing the levels of IL6, IL8 and TNF $\alpha[133,135,136]$. Such a pro-inflammatory environment is conducive to the development of many cancers, including breast cancer. In a controlled study with 178 older adults, a diet rich in fiber resulted in higher abundance of Firmicutes in the gut, with a decline of inflammatory markers IL6, IL8, TNF $\alpha$ and CRP [135]. In addition, a fiber-rich diet contributes to the estrogen milieu by means of phytoestrogens [137], which bind to ER $\beta$ in the skeletal and central nervous system, accomplishing the functions of estrogens ceased due to lower estrogen levels in old age. In the breasts, phytoestrogens competitively bind to estrogen receptor alpha (ER $\alpha$ ), preventing local estrogen signaling within an adipose-rich tissue environment. Based on the current knowledge, a supplementation with probiotic species like Lactococcus lactis, Lactobacillus rhamnosus, Bifidobacterium adolescentis, Bifidobacterium longum, Lactobacillus plantarum, Bifidobacterium breve, Bifidobacterium lactis, Lactobacillus acidophilus, Lactobacillus casei, and Lactobacillus johnsonii combined with a fiber-rich diet could be an effective strategy to prevent age-related diseases including breast cancer.

\subsection{Higher Levels of Estrogens, Breast Cancer and Microbiota}

Breast cancer growth and progression is largely regulated by steroid hormones and approximately $70 \%$ of breast cancers in postmenopausal women are estrogen receptor alpha (ER $\alpha)$-positive, hence their sensitive to estrogen. Many triple-negative breast cancers, characterized by the absence of $\mathrm{ER} \alpha$, progesterone receptor (PR) and human epidermal growth factor receptor 2 (Her2), also possess ER $\beta$ and an androgen receptor (AR) [49]. An increased concentration of circulating estrogen and a longer duration of estrogen exposure are linked with a higher risk of breast cancer in postmenopausal women [138]. Late menarche (1-year delay) and late menopause (1-year delay) are associated with a $5 \%$ reduction and a 3\% increase in the risk of developing breast cancer, respectively, highlighting the importance of the duration of estrogen exposure [139]. Multiple other risk factors such as the patient's age at the birth of their first child, breastfeeding, high alcohol intake, and obesity in the postmenopausal stage are also associated with the level of circulating estrogens. Alcohol intake is associated with a $7 \%$ increase in the risk of developing breast cancer with a moderate intake (one unit/day) and the risk increases with higher alcohol intakes. Mechanistically, alcohol intake is associated with higher estrogen levels $[140,141]$. Another modifiable risk factor, obesity, is also associated with higher estrogen levels, owing to the increased aromatization of androstenedione in the adipose tissue of postmenopausal women. Obesity is linked with a $30 \%$ increase in the risk of breast cancer development $[142,143]$. It is now known that the microbiota is a critical regulator of estrogen in the body. Enteric bacteria, by virtue of their enzymatic activity, are capable of deconjugating estrogen metabolites and reintroducing them into the circulation by increasing their systemic levels. Bacterial 
glucuronidases and glucosidases are encoded by a group of enteric bacterial genes, collectively referred to as the estrobolome [144,145]. Multiple studies have shown links between microbiota and estrogen levels (reviewed in [145]). Estrogen undergoes hepatic deconjugation to form estrogen metabolites, possessing variable potency and bioavailability. These estrogen metabolites can either undergo biliary excretion or resorption into the circulation following glucuronidation and sulfonation [146]. The majority of these enzymatic reactions are catalyzed by intestinal bacteria. In addition, enteric microbes are capable of synthesizing estrogen mimics from dietary polyphenols, which can activate both ER $\alpha$ and ER $\beta$ signaling [146]. They are also known to regulate the bioavailability of steroid hormones in the tissue microenvironment. Gut microbes can metabolize and regulate the bioavailability of androgens, progesterone and testosterone. The sulfatase activity of certain gut commensals can potentially convert inactive steroids in circulation to active estrogen. The modulation of circulatory estrogen levels in the body by enteric commensals has been demonstrated by multiple population-based studies [147-150]. In addition to steroid hormones, breast cancer is also affected by hormones derived from adipose tissue, like leptin and insulin, which are also regulated by gut microbiota. Gut microbiota impacts various aspects of hormone regulation, resulting in the alteration of circulating levels of steroid hormones and cytokines that are known to increase the risk and progression of breast cancer (Figure 2).

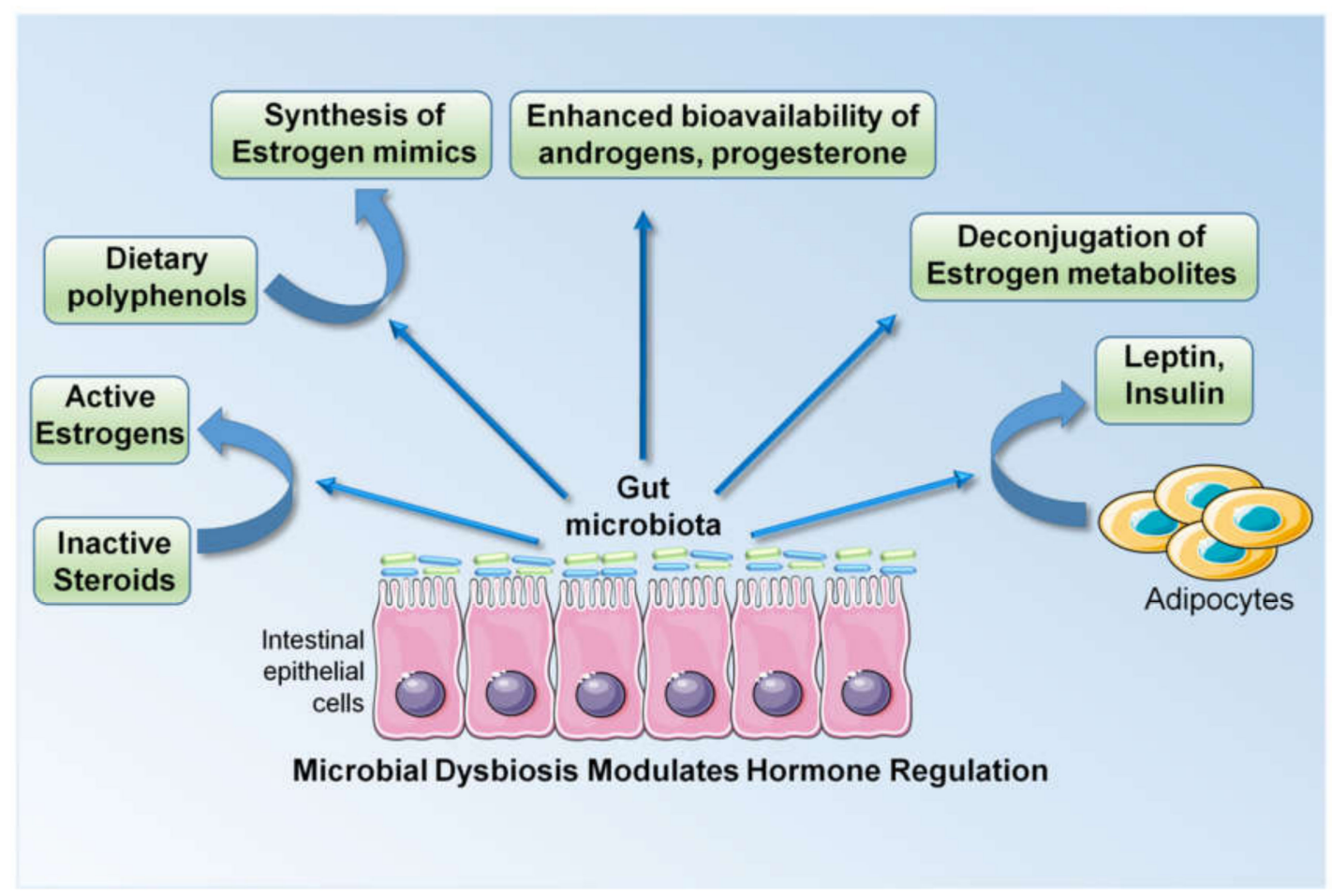

Figure 2. Changes in gut microbiota alter the levels of circulating hormones and cytokines/adipocytokines, which act as effector molecules, mediating the biological effect of dysbiosis.

\subsection{Periodontal Disease, Breast Cancer and Microbiota}

Meta-analyses of studies examining the association between periodontal disease and breast cancer have shown that periodontal disease is, indeed, an avoidable risk factor for breast cancer and can be considered for potential prevention strategies [151]. Many epidemiologic studies conducted over the years have shown an increase in the risk of esophageal, lung, pancreatic and breast cancers with periodontal disease. In 2016, an observational study on 73,737 postmenopausal women with periodontal disease was conducted [152]. Within a mean follow-up period of 6.7 years, 2124 cases of invasive breast cancer were recorded [152]. When adjusted for age, education, race/ethnicity, BMI, age at menarche and menopause, parity, maternal age at first birth, hormone use, alcohol consumption, physical activity and nonsteroidal anti-inflammatory drugs NSAIDs, the hazard ratio was $1.14(\mathrm{CI}=1.04-1.26)$ and 
when additionally adjusted for smoking status, the HR was $1.1(\mathrm{CI}=1.0-1.23)$ [152]. Non-smokers with a history of smoking within 20 years prior to study exhibited an HR of 1.36 (95\% CI, 1.05-1.77) and for current smokers, HR was 1.32 (95\% CI, 0.83-2.11) [152]. This study implies that periodontal disease positively correlates with breast cancer risk in postmenopausal women, especially former smokers [152]. Another study examined a cohort of 1337 postmenopausal women [153]. The mean follow-up period was $12.2 \pm 4.2$ years, during which there were 203 confirmed cancer cases. After adjusting for age and smoking, they did not find any significant association between periodontal disease and cancer in general. Only an increase in lung cancer risk was observed with HR 1.81, 95\% CI 1.30-2.54 [153]. In another cohort study comprising of 65,869 periodontal disease cases between 54-86 years of age, 7149 cancer cases were recorded during a mean follow-up period of 8.32 years [154]. In relation to periodontal disease, total cancer risk increased by HR 1.14 (95\% CI, 1.08-1.2). Breast cancer risk increased by HR 1.13 (95\% CI 1.03-1.23) [154]. Similar associations were also observed in other cancers, such as lung cancer (HR, 1.31; 95\% CI, 1.14-1.51), esophageal cancer (HR, 3.28; 95\% CI, 1.64-6.53), gallbladder cancer (HR, 1.73; 95\% CI, 1.01-2.95), melanoma (HR, 1.23; 95\% CI, 1.02-1.48) and stomach cancer (HR, 1.58; 95\% CI, 0.94-2.67) [154]. This study suggested that an increase in cancer risk with periodontal disease is not limited to any particular anatomical site [154]. In yet another study, a group of patients with periodontal disease, median age 49.6, were followed for 12 years and the study observed a 77\% increase in the risk of any kind of cancer with periodontal disease [155]. The age-standardized incidence rate for breast cancer in women was 2.40, 95\% CI 0.88-5.33 [155]. A study conducted on adult Brazilian women investigated 67 breast cancer patients at different stages and 134 controls [156]. Women with periodontal disease had a two to threefold higher odds ratio for breast cancer (2.72 1.18-6.27 .02) [156]. An association between the severity of periodontal disease and cancer incidence was also observed [154], which is largely mediated by oral microbial dysbiosis. Many pathogens associated with periodontal disease (PD) have also been identified with cancer lesions and are capable of promoting a pro-carcinogenic microenvironment [155]. Periodontal disease involves a complex interaction between host defense, bacteria and viruses [152,155]. A complex group of oral bacteria is known to form a biofilm on the teeth, which is capable of triggering an immune inflammatory response in the adjacent tissue. A systemic immune inflammatory response is also observed in some chronic cases of periodontal disease. Within a biofilm, quorum sensing is the primary mode of communication and involves the production and release of chemical signals called autoinducers [157], such as acylated homoserine lactones in the case of Gram-negative and oligo-peptides in Gram-positive bacteria [157]. The autoinducers regulate physiologic processes like symbiosis, virulence, competence, conjugation, antibiotic production, motility, and sporulation [157]. These chemical messengers may also trigger various signaling cascades in the host and contribute to cancer incidence.

\section{Mechanistic Insights into the Microbiota-Cancer Connection}

\subsection{Microbial Metabolites as Effector Molecules Influencing Breast Cancer}

Microbial residents of our body synthesize a plethora of metabolites including small molecules, fatty acids, vitamins, polyamines, hormones and ATP. In addition to circulating metabolites from the enteric microbes, it is now known that a community of microbes resides within the breast tissue, capable of synthesizing a myriad of signaling molecules. The local tissue of breast cancer patients has a significantly reduced population of Methylobacterium, which is known to synthesize phytohormones, cytokinin and auxin which have potent anticancer activities. Moreover, pathogenic strains of $E$. coli reside in the breast tissue of breast cancer patients, producing DNA-damaging colibactin. These strains cause double-stranded DNA breaks in vitro in HeLa cells [158]. A comprehensive list of metabolites produced by the human [25] microbiota is presented in Table 1 [22,27,159-175]. 
Table 1. Microbes produce various metabolites that influence multiple biological functions.

\begin{tabular}{|c|c|c|c|}
\hline \multicolumn{2}{|c|}{ Biological Process } & Microbial Species & Reference \\
\hline \multicolumn{2}{|l|}{ Carbohydrate metabolism } & \multirow{3}{*}{$\begin{array}{l}\text { Most gut organisms } \\
\text { Eubacterium hallii } \\
\text { Roseburia } \\
\text { Coprococcus catus } \\
\text { Megasphera elsdenii } \\
\text { Veillonella spp } \\
\text { Ruminococcus obeum } \\
\text { Bacteroidetes } \\
\text { Eubacterium rectale } \\
\text { Eubacterium hallii } \\
\text { Roseburia spp } \\
\text { Coprococcus spp } \\
\text { Faecalibacterium prausnitzii } \\
\text { Bifidobacterium spp } \\
\text { Lactobacillus spp } \\
\text { Methanobrevibacter smithii } \\
\text { Desulfovibrio spp }\end{array}$} & \multirow[b]{2}{*}{$\begin{array}{l}{[159,161,163,168]} \\
{[22]}\end{array}$} \\
\hline Parent carbohydrate & Metabolite & & \\
\hline $\begin{array}{l}\text { Polysaccharides } \\
\text { Oligosaccharides } \\
\text { Resistant starch } \\
\text { Mucins }\end{array}$ & $\begin{array}{l}\text { Acetate } \\
\text { Propionate } \\
\\
\text { Butyrate } \\
\text { Lactate } \\
\mathrm{CH}_{4} \\
\mathrm{H}_{2} \mathrm{~S} \\
\end{array}$ & & \\
\hline Fat metabolism & & Eubacterium siraeum & \\
\hline $\begin{array}{l}\text { Linoleic acid } \\
\text { Conjugated lineloic acids }\end{array}$ & & $\begin{array}{l}\text { Roseburia faecis } \\
\text { Roseburia intestinalis } \\
\text { F. prausnitzii } \\
\text { Bifidobacterium }\end{array}$ & [27] \\
\hline Stearic acid & & $\begin{array}{l}\text { Propionibacterium } \\
\text { Lactobacillus spp } \\
\text { Bifidobacterium breve }\end{array}$ & \\
\hline $\begin{array}{l}\text { Fatty acids } \\
\text { Short chain fatty acids(SCFA) } \\
\text { Branched chain fatty acid(BCFA) } \\
\text { (Isobutyrate from valine; } \\
\text { 2-methylbutyrate from isoleucine; } \\
\text { Isovalerate from leucine) }\end{array}$ & & $\begin{array}{l}\text { Propionibacterium freudenreichii } \\
\text { Roseburia inulinivorans } \\
\text { Roseburia hominis } \\
\text { Butyrivibrio fibrisolvens } \\
\text { Clostridia Peptostreptococci } \\
\text { Peptococci }\end{array}$ & \\
\hline Protein metabolism & & $\begin{array}{l}\text { Akkermansia } \\
\text { Bifidobacterium }\end{array}$ & {$[166,172]$} \\
\hline Bile metabolism & $\begin{array}{l}\text { Cholic acid } \\
\text { Chenodeoxycholic acid } \\
\text { Deoxycholic acid } \\
\text { Lithocholic acid } \\
\text { Ursodeoxycholic acid }\end{array}$ & $\begin{array}{l}\text { Bacteroides } \\
\text { Bifidobacterium } \\
\text { Clostridium } \\
\text { Lactobacillus } \\
\text { Listeria } \\
\text { Clostridium } \\
\text { Eubacterium } \\
\text { Bacteroides } \\
\text { Clostridium } \\
\text { Egghertella } \\
\text { Peptostreptococcus } \\
\text { Ruminococcus } \\
\text { Eubacterium }\end{array}$ & [170] \\
\hline Vitamin synthesis & $\begin{array}{l}\text { Biotin } \\
\text { Cobalamin } \\
\text { Folate } \\
\text { Nicotinic acid } \\
\text { Panthothenic acid } \\
\text { Pyridoxine } \\
\text { Riboflavin } \\
\text { Thiamine } \\
\end{array}$ & $\begin{array}{l}\text { Bacteroidetes (Most important) } \\
\text { Fusobacteria } \\
\text { Proteobacteria } \\
\text { Firmicutes } \\
\text { Actinobacteria }\end{array}$ & {$[165,166]$} \\
\hline
\end{tabular}


Table 1. Cont.

\begin{tabular}{|c|c|c|c|}
\hline \multicolumn{2}{|c|}{ Biological Proces } & \multirow[b]{3}{*}{$\begin{array}{l}\text { Clostridium spp. } \\
\text { Eubacterium ramulus } \\
\text { Lactobacillus mucosae } \\
\text { Enterococcus faecium } \\
\text { Finegoldia magna } \\
\text { Veillonella sp } \\
\text { Slakia isoflavoniconvertens } \\
\text { Slakia equolifaciens } \\
\text { Adlercreutzia equolifaciens }\end{array}$} & \multirow[b]{3}{*}[166,171,173]{} \\
\hline Phytochemical met & olism & & \\
\hline $\begin{array}{l}\text { Phytochemical } \\
\text { Flavonoids } \\
\text { Lignans } \\
\text { Ferulic acid } \\
\text { Isofllavones } \\
\text { Caretenoids } \\
\text { Glucosinolates } \\
\text { Isothiocyanates } \\
\text { Stilbens } \\
\text { Organosulfur } \\
\text { compounds }\end{array}$ & $\begin{array}{l}\text { Process } \\
\text { Deglycosylation } \\
\text { Ring fission } \\
\text { Dehydroxylation }\end{array}$ & & \\
\hline $\begin{array}{l}\text { Antibiotics } \\
\text { Lugdunin } \\
\text { Herbicolin I } \\
\text { Andrimid } \\
\text { Polykitide synthase }\end{array}$ & & $\begin{array}{l}\text { Staphylococcus lugdunensis } \\
\text { Pantoea agglomerans } \\
\text { P. Vagans } \\
\text { Clostridium sp. }\end{array}$ & {$[172,173]$} \\
\hline $\begin{array}{l}\text { Bacteriocins } \\
\text { Nicin } \\
\text { Lacticin } 3147 \\
\text { Butyrivibriocin } \\
\text { Pediocin } \\
\text { Sakacin A } \\
\text { Lactacin F } \\
\text { Lactococcin G } \\
\text { Enterolysin } \\
\text { Helvecticin I } \\
\text { Enterocin I F4-9 } \\
\text { Glycocin F }\end{array}$ & & $\begin{array}{l}\text { Lactococcus lactis } \\
\text { Butyrivibrio fibrisolvens } \\
\text { Pedicoccus acidilactici } \\
\text { Lactobacillus sakei } \\
\text { Lactobacillus acidophillus } \\
\text { Enterococcus faecium } \\
\text { Lactobacillus helveticus } \\
\text { Enterococcus sp. } \\
\text { Lactobacillus plantarum }\end{array}$ & {$[85,174,175]$} \\
\hline
\end{tabular}

\subsubsection{Short Chain Fatty Acids (SCFAs)}

SCFAs such as butyrate, propionate and acetate are the most important and well-studied microbial metabolites. SCFAs, produced in the small intestine, are the microbial messengers of the immune system. Bacteroides, which are more efficient in metabolizing dietary polysaccharides such as cellulose, produce acetate and propionate, while their less efficient partners, the Firmicutes, produce butyrate. Major immunologic functions within the gut are carried out by butyrate. It is the predominant energy source for colonocytes and is indispensable for the induction of T-regulatory cells. Comprehensive studies by Furusawa et al. and Smith et al. have demonstrated the role of microbial butyrate in the differentiation/maturation and maintenance of the homeostasis of FOXP3 expression in Treg cells, but not in their survival and proliferation $[176,177]$. Multiple studies have described the role of SCFAs in various aspects of immune regulation $[14,16,177-180]$. While most of the propionate is degraded in the liver, acetate is the only SCFA distributed throughout the circulation. SCFAs can induce both intracellular and extracellular signaling events [180]. They are also known to induce various GPCRs (GPR41, GPR43) or orphan fatty acid receptors [180]. In vitro, GPR41 and GPR43 have been shown to impede the invasion potential of MCF7 and MDA-MB-231 cells by inhibiting Hippo-Yap and MAPK signaling, respectively [181]. Interestingly, the binding of SCFAs to GPR41 has been shown to drive leptin synthesis. In addition, they can activate an array of cell surface receptors, including the niacin receptor GPR109A [182] and olfactory receptor 51E2, which are expressed on a variety of epithelial and immune cells $[179,180]$. The butyrate receptor GPR109A is expressed in healthy breast epithelial cells but is lost in breast cancers, irrespective of the cancer subtype [182]. Using multiple murine models, it has been demonstrated that butyrate-induced GPR109A activation inhibits cell survival and anti-apoptotic gene expression, while its deletion increases breast cancer incidence, as well as lung metastasis [182]. SCFAs can enter the cell via sodium channels (SLC5A8), where butyrate and propionate can inhibit histone deacetylase 1(HDAC1), 3 and histone acetyltransferases (HATs), thereby influencing transcriptional regulation. Butyrate is also known to antagonize PPAR $\gamma$ [180]. Unlike butyrate, acetate has been reported to be an instigator of cancers including liver, brain, prostate and breast cancer [183]. In cancer cells, acetate can serve as a source of nutrition required for lipid 
biosynthesis and can acetylate histones, leading to epigenetic modifications [183]. It can also lead to the considerable post-translational modification of proteins, altering their functions [183].

\subsubsection{Amino Acid Metabolism (Tryptophan, Arginine, Lysine)}

Gut microbes such as Lactobacilli metabolize dietary tryptophan to various indole derivatives like indole-3-aldehyde. These indoles act as ligands for the Aryl hydrocarbon receptor (AhR) receptor. The AhR pathway is a central pathway of immune regulation in the gastrointestinal tract GI tract [180]. In breast cancer, a number of studies have suggested the important role of tryptophan metabolism and AhR signaling [184-187]. Amplified tryptophan metabolism and the upregulation of AhR receptors induce apoptosis resistance in breast cancer $[186,187]$. It is also known that the pregnane $X$ receptor (PXR) gets modulated by microbial-specific indoles and affects the mucosal integrity via Toll-like receptors (TLRs). This is an interesting example of communication between the intestinal microbes and the PXR-TLR4 axis [188]. The activation of orphan nuclear receptors, PXR and steroid and xenobiotic receptors (SXRs), by endobiotics and xenobiotics, decreases growth and induces apoptosis in breast cancer cells $[189,190]$. Diamines, cadaverines or putrescines similar to spermines and spermidines, are products of the bacterial decarboxylation of amino acids lysine and arginine. These foul-smelling compounds maintain the $\mathrm{pH}$ of the environment making it conducive to bacterial growth. Multiple bacterial commensals, including Shigella flexneri, Shigella sonnei, Escherichia coli, and Streptococci encode enzymes LdcC and CadA are responsible for cadaverine biosynthesis (reviewed in [191]). Cadaverine has been shown to inhibit breast cancer cell proliferation, migration, invasion and stemness and to induce mesenchymal to epithelial transition both in vitro and in vivo via TAAR receptors [192]. It reduces tumor infiltration to the surrounding tissue, as well as reducing the distant metastasis of breast tumors [192]. Cadaverine biosynthesis is markedly reduced in early stages of breast cancer, rendering the developing tumors characteristically more glycolytic [192]. It could be attributed to the decreased biodiversity in breast cancers compared to healthy states.

\subsubsection{Secondary Bile Acids}

Another important class of cancer-associated metabolites are secondary bile acids (SBAs), which are synthesized by all major classes of intestinal bacteria, including Firmicutes and Bacteroidetes, and are recognized as risk factor for liver and colon cancers. Primary bile acids are converted into SBAs by intestinal microbes in a series of successive deconjugation and dihydroxylation reactions. One secondary bile acid, lithocholic acid (LCA), has been shown to inhibit breast cancer cell proliferation and aggressiveness via TGR5. It induces the oxidative phosphorylation (OXPHOS) and tricarboxylic acid (TCA) cycle and inhibits epithelial to mesenchymal transition (EMT) and vascular endothelial growth factor (VEGF) levels in breast cancer [193]. As such, lower levels of LCA were detected in early stage breast cancer patients compared to healthy controls [193]. It was recently demonstrated that LCA, via its receptors, TGR5 and CAR, upregulates KEAP1, while downregulating NRF2 expression, which, in turn, leads to iNOS induction. Consequent protein and lipid oxidation cause cytotoxicity in breast cancer cells. With advanced breast cancer stages, a decrease in the microbial diversity and, hence, a decreased LCA level, results in the modulation of oxidative stress in the breast cancer cells, leading to a poor prognosis [191,194]. On the other hand, deoxycholate, another secondary bile acid, has been shown to promote mammary tumor cell survival by downregulating pro-apoptotic proteins [195].

\subsubsection{Bacteriocins/Peptides and Antibiotics}

Bacteriocins are bioactive compounds produced by commensals, which are capable of inhibiting the growth and multiplication of other strains-notably, pathogens. These are valuable molecules, synthesized mostly by anaerobic gut commensals. Metagenome mining from datasets of the human microbiome project revealed codes for about 4875 bacteriocins of different types that are differentially distributed in various body sites [81]. Recently, antibiotic Lugdunin has been identified, which is synthesized by nasal commensal Staphylococcus lugdunensis and which prevents S. aureus colonization 
and infection [174]. While these microbial bacteriocins/peptides/antibiotics might not directly modify breast cancer risk, their therapeutic significance is tremendous. With advances in the understanding of dysbiosis, multiple carcinogenic strains are being discovered and eliminating pathogens to prevent/treat cancers or to improve treatment using broad-spectrum antibiotics seems lucrative, but collateral damage caused by broad-spectrum antibiotics is also well appreciated. Bacteriocins and peptides, on the other hand, have a narrow spectrum of activity, hence why they only inhibit closely related species. Additionally, they show higher activity at lower concentrations and do not induce antibiotic tolerance or resistance towards pathogens due to their unique mode of action [175]. Colonization with these microbial species can potentially eliminate pathogens, improving cancer outcomes. Many studies have described the therapeutic significance of bacterial species in treating cancers, mostly via immune modulation. However, inhibiting the colonization of pathogens by synthesizing small bioactive compounds could be a possible mechanism as well.

\subsection{Microbiota Modulates the Metabolism of Xenobiotics}

The most important consequence of the coevolution of humans with an army of commensals is the convergence of their enzymatic machineries in order to metabolize complex dietary components, pharmaceutical and non-traditional xenobiotics like environmental pollutants. The classes of microbial enzymes associated with xenobiotic metabolism include hydrolases, lyases, oxidoreductases and transferases [196], which are encoded by all major taxa. The mechanisms of the enzymatic reactions and interactions with hosts in the human body, e.g., the removal of glucuronide from chemotherapy drug Irinotecan by microbial hydrolases, increases their absorption and half-lives [196]. Lyases are responsible for breaking down complex polysaccharides. Microbes like Eubacterium coprostanoligenes reduce cholesterol to coprostanol, which is not absorbable and is subsequently excreted [197], keeping cholesterol levels in check. However, as sometimes encountered with dietary pollutants, the gut microbes can synthesize undesirable products. For example, food additive and artificial sweetener cyclamate is hydrolytically cleaved to form cyclohexamine, a potent carcinogen. Similarly, seemingly safe sweeteners, e.g., stevioside and xylitol, can also be metabolized by gut commensals via as yet undiscovered mechanisms [196]. The altered metabolism of xenobiotics by dysbiotic microbiota can influence cancer growth and progression.

\subsection{Microbiota Induces Systemic Immune Modulation and Inflammatory Response in Breast Cancer}

The gut microbiota is undoubtedly the stimulator of systemic immunity [198], which directly impacts breast cancer risk and aggressiveness. The induction of mammary adenocarcinoma was observed in response to enteric infection with Helicobacter hepaticus in Rag 2-deficient C57BL/6 Apc Min/+ mice [17]. Enteric infection with Helicobacter hepaticus induced a TNF $\alpha$-dependent innate immune response, favoring mammary tumorigenesis, while mice lacking the adaptive arm of the immune system did not develop any mammary tumors in response to the bacterium [17]. In addition, the $H$. hepaticus-induced breast adenocarcinomas exhibited an increased infiltration of F4/80+ macrophages and the adoptive transfer of the T25+ TReg cells inhibiting mammary tumors [17]. However, the inhibition was much more efficient when TReg cells were subjected to a prior $H$. hepaticus challenge [17], suggesting that low-grade infection early in life can induce a tolerance to tumorigenesis. Enteric infection with pathogens like Helicobacter pylori prolongs the immune activation and, hence, leads to the sustained elevation of cycloxygenase 2 (COX-2) and prostaglandin 2 (PGE2) production, increasing the risk of cancer in susceptible individuals [199]. Interestingly, gut commensals can also initiate a systemic response that overrides pro-carcinogenic signals, preventing the progression of low-grade lesions to high-grade cancers in mice models by downregulating the systemic pro-inflammatory index in the epithelial tissue remote to the gut [198]. The microbiota regulates both inflammatory neutrophils and lymphocytes [200]. In breast cancer patients, crosstalk between microbes, systemic IL-6, and neutrophils has been observed $[19,201]$. The depletion of neutrophils by anti-Ly-6G antibodies resulted in the complete inhibition of tumor development in a bacteria-triggered mouse 
model of breast cancer $[202,203]$. Leukocyte infiltration is known to both prevent and promote tumor progression in a context-dependent manner $[18,204]$. In postmenopausal women, it is a determinant of breast cancer incidence and mortality [205]. Elevated neutrophil counts are known to be predictors of a poor prognosis in breast cancer patients [206]. A threefold higher early recurrence was observed in breast cancer patients with neutrophil to lymphocyte ratios higher than $2.5(p<0.001)$ [205] and negatively correlated with 5-year survival in 316 patients $(p<0.0001)$ [206]. In lymph node-positive patients, a higher ratio of lymphocytes (CD8+ effector T cells) correlated with lower relapse and death rates $(p<0.0001)$. Local inflammation in the breast tissue in response to enteric infection suggests a retrograde translocation of microbes from the gut to the mammary tissue, which potentially increases systemic inflammation, thereby promoting breast tumorigenesis [202]. Commensal microbes also play an important role in modulating therapy response. CD8+ T cells, or natural killer (NK) cells, have been found to be the most potent in eliminating breast tumor cells [207]. In a healthy gut, contact with the commensals Sphingomonas of Proteobacteria phylum $[207,208]$ induces effector CD8+T cell maturation. In a dysbiotic state, microbiota-mediated CD8+T cell maturation and CD8+ antitumor cytotoxicity is hampered [208]. The microbiota can actively hinder the therapy response in breast cancer patients via immune modulation, since an inflammatory tumor microenvironment and an erroneous immune response is known to induce chemotherapy resistance in breast cancer [204]. Overall, human microbiota induce systemic immune modulation and inflammation and a dysbiotic microbiota may modulate breast cancer initiation and progression by manipulating various components of the host's immune system.

\subsection{Microbial Dysbiosis May Modulate Response to Cancer Therapy}

Evidently, a healthy microbiota is indispensable for an optimum therapeutic response and dysbiotic microbiota could be the underlying reason for variable response to similar therapeutic strategies in different patients. Approximately forty chemotherapeutic drugs have been shown to be metabolized by the gut microbiota [196]. Some of the most commonly used cancer drugs known to be regulated by the microbiota include cisplatin, oxaliplatin, doxorubicin, cyclophosphamide, and misonidazole [209]. Diverse phyla are known to mediate drug metabolism via reactions like proteolytic degradation, isoxazole scission, denitration, deconjugation, acetylation/deacetylation, amine formation and/or hydrolysis, as well as by physical adherence to the drugs [46]. The gastrointestinal microbial population is also known to influence the response to radiation and immunotherapy [209]. Gut commensals induce tumor-associated myeloid cells in order to synthesize inflammatory cytokines like TNF $\alpha$ and IL1 $\beta$ in a TLR4-dependent manner, thus influencing adoptive T cell activation and, in turn, determining the efficacy of immunotherapy. Studies have also shown that, compared to germfree animals, conventional mice are more prone to ionizing radiation-induced DNA damage in peripheral leukocytes [210]. Moreover, the response to radiotherapy varies at different times during the day in concert with gut microbial metabolic activity, suggesting a potential relationship between the two [210]. Chemo and radiotherapy-associated systemic and organ toxicities are responsible for significant morbidities and are thought to be regulated by the microbiota. The association between microbiome and therapy-associated toxicities was elegantly described by the Translocation, Immunomodulation, Metabolism, Enzymatic Degradation and Reduced Diversity (TIMER) hypothesis [211]. Most gastrointestinal toxicities are known to be regulated by bacterial GUS genes encoded by the majority of gut commensals, and efforts to develop inhibitors of bacterial GUS are underway, with the hope of preventing chemotherapy-associated GI toxicities [212]. Certain probiotic lactobacillus strains have proved to be effective in preventing toxicities in colorectal cancers [213].

\subsection{Beneficial Bugs as Drugs}

In recent years, multiple studies have utilized probiotic bacterial strains for the prevention and treatment of breast cancer growth and metastasis, as well as improving the response to chemotherapy and immunotherapy (reviewed in [214-217]). Lactobacillus reuteri, a bacterium found in breast milk, 
is well known for its immunomodulatory effects and has been shown to inhibit the proliferation of breast cancer cells [218]. In a series of studies using multiple mouse models, it has been demonstrated that a healthy microbiota can be helpful in overcoming genetic, as well as environmental (diet-induced), predisposition to breast cancer development [13]. Using a Western diet-induced outbred Swiss mouse model and an FVB strain Her2-mutant spontaneous breast cancer model, it has been shown that oral administration of Lactobacillus reuteri inhibits mammary tumorigenesis by CD4+CD25+ lymphocyte stimulation [13]. In a Western diet-induced model, L. reuteri administration resulted in the inhibition of mammary atypical hyperplasia, with the restoration of FOXP3-positive cells in mammary lymph nodes, which are depleted in the absence of probiotic treatment, as well as a decrease in mast cell population [13]. L. reuteri administration also resists diet-induced obesity, with higher systemic levels of IL10 and lower levels of IL17 in mice [13]. In a transgenic breast cancer model, a reduced tumor burden and increased disease-free survival is observed when orally treated with $L$. reuteri [13]. In tumor-bearing mice, an increase in intra-tumoral apoptosis, necrosis and the downregulation of NFKB and c-Jun pathways in the neoplastic cells is also evident [13]. The adoptive transfer of CD4+CD45RBloCD25+ cells from mice exposed to L. reuteri is sufficient to regress tumors in a transgenic breast cancer model [13]. Interestingly, a transgenerational study demonstrated an increased risk of breast cancer and obesity in the second-generation progeny of mice that were given a modern Western diet. Interestingly, these mice exhibited gut microbiota changes that were carried across generations [219]. However, when the second-generation progeny was administered with a continuous dosage of L. reuteri, the cancer risk significantly reduced [219]. Interestingly, the administration of milk fermented with Lactobacillus casei CRL431 in mice before tumor injection inhibited tumor growth, angiogenesis and lung metastasis by reducing the infiltration of macrophages into the tumor, as well as lungs, while enhancing the CD4+ and CD8+ antitumor immune response. Probiotic Lactobacillus casei CRL431 delays tumor growth, even when it is administered after tumor detection [220]. Live cells, heat-killed cells, as well as the cytoplasmic fractions of Enterococcus faecalis and Staphylococcus hominis microbes isolated from human milk, all exhibit anti-breast cancer potential. While all the fractions caused a significant reduction in the proliferation of breast cancer cells, Enterococcus faecalis exhibited a better dose and time response [221]. Lactobacillus acidophilus has been shown to improve the survival of breast tumor-bearing mice by inducing increased immune cell proliferation and interferon $\gamma$ (IFN $\gamma$ ) production, while downregulating IL4 production [20]. Cultured supernatants from Lactobacillus crispatus and Lactobacillus rhamnosus induce cell death in the triple-negative breast cancer cell line MDA-MB-231 and downregulate hypoxia-associated genes HIF1 $\alpha$, HSP90 and SLC2A1 [222]. L. rhamnosus GG has also been shown to reduce GLUT 1 expression in MDA-MB-231 cells. GLUT 1 inhibition can prevent metastasis via matrix metallopeptidase 2 (MMP-2) and JNK pathways. The nano delivery of Lactobacillus brevis improved NK cell activity and IFN- $\gamma$ and IL-17 levels, inhibiting metastasis to vital organs, in a mouse model of breast cancer [215]. Together, these preclinical studies have formed a basis for clinical studies. Few ongoing clinical trials are investigating the impact of beneficial bacteria in breast cancer patients (Table 2). Subjects with stage I-III breast adenocarcinoma will be given a probiotic (Prima Defense Ultra containing 13 species of beneficial bacteria) for 2-4 weeks and the mean number of cytotoxic T lymphocytes (CD8+ cells) will be evaluated (ClinicalTrials.gov identifier: NCT03358511). An interventional double-blind, randomized, placebo-controlled pilot study is currently investigating the impact of probiotic natural health product RepHresh Pro-B, containing Lactobacillus rhamnosus GR-1 and Lactobacillus reuteri RC-14, on breast microbiota and inflammation markers (ClinicalTrials.gov identifier: NCT03290651). Another randomized study is investigating the impact of MRx0518 (a proprietary strain of bacterium) on breast tumor biomarkers and overall survival (ClinicalTrials.gov identifier: NCT03934827). While in vitro and in vivo studies have highlighted the potential benefits of probiotics in the prevention and treatment of breast cancer (reviewed in [216,217]), large-scale clinical studies are needed to prove the benefits of adding beneficial bioactive strategies to the existing repertoire of drugs as combination strategies. 
Table 2. Bugs as drugs.

\begin{tabular}{|c|c|c|c|}
\hline Bug & Animal Model & Mode of Action & Reference \\
\hline Lactobacillus reuteri & $\begin{array}{l}\text { FVB strain Her2 } \\
\text { Swiss mice }\end{array}$ & $\begin{array}{c}\text { Inhibits mammary tumorigenesis by } \\
\text { CD4+CD25+ lymphocyte } \\
\text { stimulation }\end{array}$ & [13] \\
\hline Lactobacillus casei CRL431 & $\begin{array}{l}\text { 4T1 syngeneic breast cancer } \\
\text { model in Balb/C mice }\end{array}$ & $\begin{array}{l}\text { Inhibits tumor growth, } \\
\text { vascularization and lung metastasis } \\
\text { in mice by reducing infiltration of } \\
\text { macrophages into the tumor and; } \\
\text { enhances CD4+ and CD } 8+ \\
\text { antitumor immune response }\end{array}$ & [220] \\
\hline $\begin{array}{l}\text { Lactobacillus casei } \\
\quad \text { Shirota }\end{array}$ & $\begin{array}{l}4 \mathrm{~T} 1 \text { syngeneic breast cancer } \\
\text { model in Balb/C mice }\end{array}$ & Reduces breast cancer incidence & [216] \\
\hline Lactobacillus acidophilus & $\begin{array}{l}\text { 4T1 syngeneic breast cancer } \\
\text { model in Balb/C mice }\end{array}$ & $\begin{array}{l}\text { Improves survival of breast tumor } \\
\text { bearing mice } \\
\text { Increased immune cell proliferation } \\
\text { Increased IFN } \gamma \text { production } \\
\text { Decreased IL4 production }\end{array}$ & [20] \\
\hline Lactobacillus brevis & $\begin{array}{l}\text { 4T1 syngeneic breast cancer } \\
\text { model in Balb/C mice }\end{array}$ & $\begin{array}{l}\text { Inhibits metastasis to vital organs } \\
\text { Improves NK cell activity } \\
\text { Increased IFN- } \gamma \\
\text { Increased IL-17 levels }\end{array}$ & [215] \\
\hline
\end{tabular}

\section{Conclusions}

Breast cancer is a multifactorial disease, resulting from the interaction between genetic, epigenetic and environmental factors. Owing to the vastness of the metagenome, we are only beginning to understand its role in health and disease in general. Microbial dysbiosis in relation to the many established risk factors of breast cancer and its role in treatment response has been observed and described by many investigators. Genetics undoubtedly plays an important role in cancer incidence, but it only accounts for less than $10 \%$ of breast cancer cases, suggesting that environmental factors and the metagenome can play bigger roles in breast cancer incidence and progression. We are a long way from completely understanding the microbiota-breast cancer connection, but the current knowledge indicates a magnitude of roles; in a nutshell, an impaired microbiota can directly affect adiposity by altering energy harvest efficiency and synthesizing free fatty acids, which, in turn, can lead to hormonal imbalance. Optimum levels of steroid hormones, most importantly estrogen, are largely dependent on the metabolic activity of the gut microbiota, which are the central regulators of systemic immunity. Communities of organ-specific microbial commensals are also known to produce numerous active metabolites, including virulence factors, toxins, fatty acids, vitamins and cofactors, potent enough to activate various signaling cascades. All of these factors taken together can contribute to the overall risk of breast carcinogenesis. Moreover, the human microbiota can determine the response to cancer therapy by various mechanisms, as described above, and thus can positively or negatively affect the outcome (Figure 3). The microbiota/microbiome therefore deserves a special focus in our quest to understand breast cancer and the search for superior strategies to deal with it. 


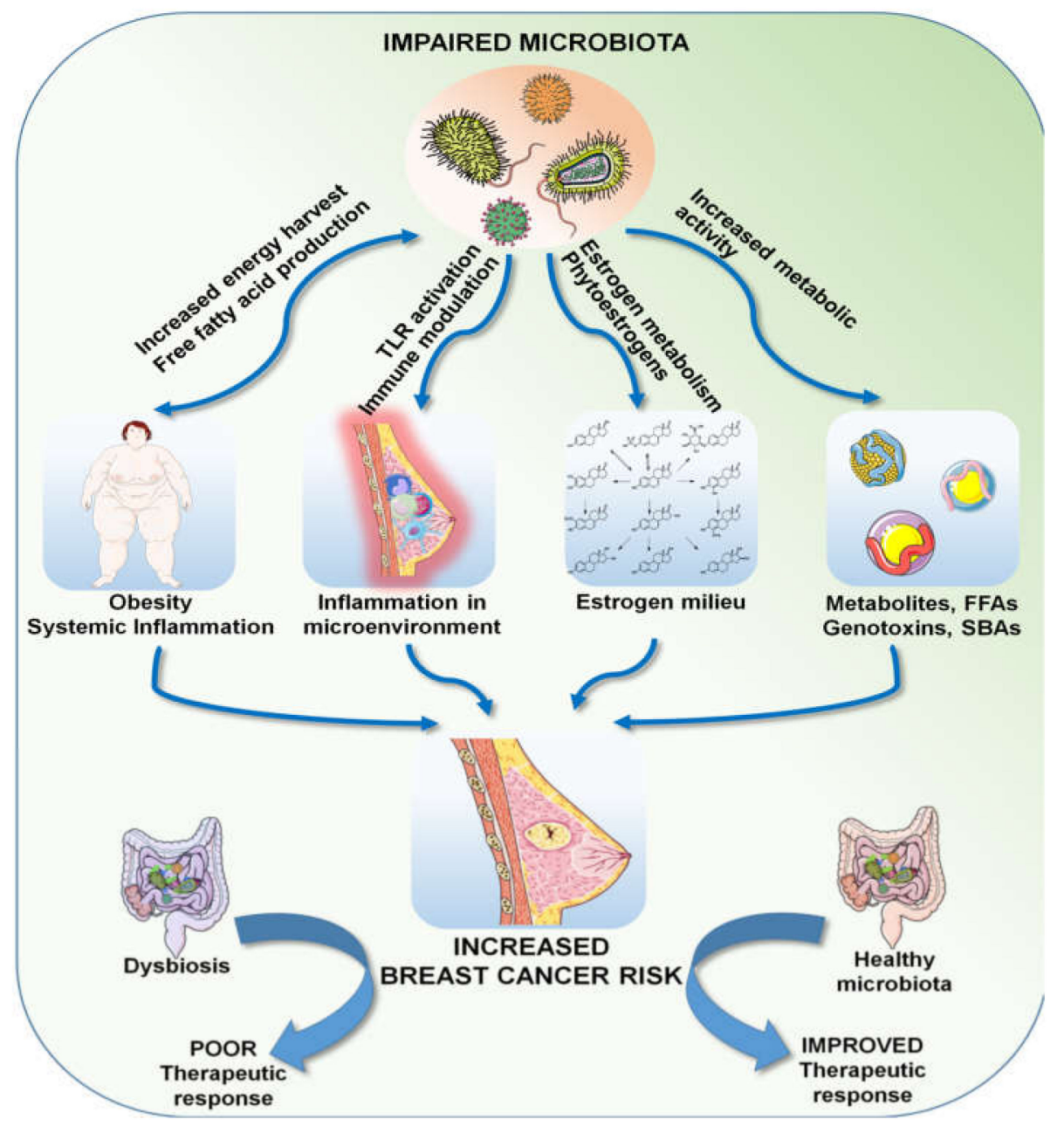

Figure 3. Multifaceted effects of a dysbiotic microbiota.

Author Contributions: S.P. and D.S. wrote this review together. All authors have read and agreed to the published version of the manuscript.

Funding: This research was funded by NCI NIH R01CA204555 and Breast Cancer Research Foundation (BCRF) 90047965 (to DS).

Conflicts of Interest: The authors declare no conflict of interest.

\section{Abbreviations}

IBD Inflammatory bowel disease

BMI Body mass index

TNBC Triple-negative breast cancer

IBC Inflammatory breast cancer

E coli Escherichia coli

SCFA Short chain fatty acids

IL Interleukin

TNF Tumor necrosis factor

CRP $\quad C$ reactive protein

ER $\beta \quad$ Estrogen receptor beta

PD Periodontal disease

NSAID Non-steroidal anti-inflammatory drugs

HR Hazard ratio

$\mathrm{ER} \alpha \quad$ Estrogen receptor alpha 
$\begin{array}{ll}\text { AR } & \text { Androgen receptor } \\ \text { PR } & \text { Progesterone receptor } \\ \text { Her2 } & \text { Human epidermal growth factor receptor } 2 \\ \text { GPCR } & \text { G-protein coupled receptor } \\ \text { HAT } & \text { Histone acetyltransferases } \\ \text { AhR } & \text { Aryl hydrocarbon receptor } \\ \text { GI } & \text { Gastrointestinal } \\ \text { SBA } & \text { Secondary bile acids } \\ \text { LCA } & \text { Lithocholic acid } \\ \text { TCA } & \text { Tricarboxylic acid } \\ \text { EMT } & \text { Epithelial to mesenchymal transition } \\ \text { VEGF } & \text { Vascular endothelial growth factor } \\ \text { COX-2 } & \text { Cyclooxygenase 2 } \\ \text { PGE2 } & \text { Prostaglandin E2 } \\ \text { TLR } & \text { Toll-like receptors } \\ \text { TIMER } & \text { Translocation, Immunomodulation, Metabolism, Enzymatic degradation and Reduced diversity }\end{array}$

\section{References}

1. Fernández, M.F.; Reina-Pérez, I.; Astorga, J.M.; Rodríguez-Carrillo, A.; Plaza-Díaz, J.; Fontana, L. Breast Cancer and Its Relationship with the Microbiota. Int. J. Environ. Res. Public Health 2018, 15, 1747. [CrossRef] [PubMed]

2. Qin, J.; Li, R.; Raes, J.; Arumugam, M.; Burgdorf, K.S.; Manichanh, C.; Nielsen, T.; Pons, N.; Levenez, F.; Yamada, T.; et al. A human gut microbial gene catalogue established by metagenomic sequencing. Nature 2010, 464, 59-65. [CrossRef] [PubMed]

3. Jin, C.; Lagoudas, G.K.; Zhao, C.; Bullman, S.; Bhutkar, A.; Hu, B.; Ameh, S.; Sandel, D.; Liang, X.S.; Mazzilli, S.; et al. Commensal Microbiota Promote Lung Cancer Development via $\gamma \delta$ T Cells. Cell 2019, 176, 998-1013. [CrossRef] [PubMed]

4. Rose, U.D.; Vetizou, M.; Roy, S.; Edwards, B.; Peck, M.; Smith, L.; Robles, A.; Harris, C.; Difilippantonio, S.; Trinchieri, G. Role of the Microbiota in Primary Lung Cancer Initiation and Progression. J. Immunol. 2019, 202, 190-191.

5. Gomes, S.; Cavadas, B.; Ferreira, J.; Marques, P.; Monteiro, C.; Sucena, M.; Sousa, C.; Vaz Rodrigues, L.; Teixeira, G.; Pinto, P.; et al. Microbiota profile of Non-small Cell Lung Cancer (NSCLC): The study of a large cohort. ERJ Open Res. 2019, 5, PP101.

6. Riquelme, E.; Zhang, Y.; Zhang, L.; Montiel, M.; Zoltan, M.; Dong, W.; Quesada, P.; Sahin, I.; Chandra, V.; San Lucas, A.; et al. Tumor Microbiome Diversity and Composition Influence Pancreatic Cancer Outcomes. Cell 2019, 178, 795-806. [CrossRef]

7. Tumor Microbiome Composition Influences Pancreatic Cancer Survival. Cancer Discov. 2019.

8. Archibugi, L.; Signoretti, M.; Capurso, G. The Microbiome and Pancreatic Cancer: An Evidence-based Association? J. Clin. Gastroenterol. 2018, 52, S82-S85. [CrossRef]

9. Ma, X.; Chi, C.; Fan, L.; Dong, B.; Shao, X.; Xie, S.; Li, M.; Xue, W. The Microbiome of Prostate Fluid Is Associated With Prostate Cancer. Front. Microbiol. 2019, 10. [CrossRef]

10. Banerjee, S.; Alwine, J.C.; Wei, Z.; Tian, T.; Shih, N.; Sperling, C.; Guzzo, T.; Feldman, M.D.; Robertson, E.S. Microbiome signatures in prostate cancer. Carcinogenesis 2019, 40, 749-764. [CrossRef]

11. Massari, F.; Mollica, V.; Di Nunno, V.; Gatto, L.; Santoni, M.; Scarpelli, M.; Cimadamore, A.; Lopez-Beltran, A.; Cheng, L.; Battelli, N.; et al. The Human Microbiota and Prostate Cancer: Friend or Foe? Cancers 2019, 11, 459. [CrossRef] [PubMed]

12. Smith, A.; Pierre, J.F.; Makowski, L.; Tolley, E.; Lyn-Cook, B.; Lu, L.; Vidal, G.; Starlard-Davenport, A. Distinct microbial communities that differ by race, stage, or breast-tumor subtype in breast tissues of non-Hispanic Black and non-Hispanic White women. Sci. Rep. 2019, 9, 11940. [CrossRef] [PubMed]

13. Lakritz, J.R.; Poutahidis, T.; Levkovich, T.; Varian, B.J.; Ibrahim, Y.M.; Chatzigiagkos, A.; Mirabal, S.; Alm, E.J.; Erdman, S.E. Beneficial bacteria stimulate host immune cells to counteract dietary and genetic predisposition to mammary cancer in mice. J. Cancer 2014, 135, 529-540. [CrossRef] [PubMed] 
14. Viaud, S.; Daillère, R.; Boneca, I.G.; Lepage, P.; Langella, P.; Chamaillard, M.; Pittet, M.J.; Ghiringhelli, F.; Trinchieri, G.; Goldszmid, R.; et al. Gut microbiome and anticancer immune response: Really hot Sh*t! Cell Death Differ. 2015, 22, 199-214. [CrossRef] [PubMed]

15. Ma, C.; Han, M.; Heinrich, B.; Fu, Q.; Zhang, Q.; Sandhu, M.; Agdashian, D.; Terabe, M.; Berzofsky, J.A.; Fako, V.; et al. Gut microbiome-mediated bile acid metabolism regulates liver cancer via NKT cells. Science 2018, 360, eaan5931. [CrossRef]

16. Spiljar, M.; Merkler, D.; Trajkovski, M. The Immune System Bridges the Gut Microbiota with Systemic Energy Homeostasis: Focus on TLRs, Mucosal Barrier, and SCFAs. Front. Immunol. 2017, 8, 1353. [CrossRef]

17. Rao, V.P.; Poutahidis, T.; Ge, Z.; Nambiar, P.R.; Boussahmain, C.; Wang, Y.Y.; Horwitz, B.H.; Fox, J.G.; Erdman, S.E. Innate Immune Inflammatory Response against Enteric Bacteria Helicobacter hepaticus Induces Mammary Adenocarcinoma in Mice. Cancer Res. 2006, 66, 7395-7400. [CrossRef]

18. Coussens, L.M.; Pollard, J.W. Leukocytes in mammary development and cancer. Cold Spring Harb. Perspect. Biol. 2011, 3, a003285. [CrossRef]

19. Rutkowski MR, S.T.; Svoronos, N.; Allegrezza, M.J.; Tesone, A.J.; Perales-Puchalt, A.; Brencicova, E.; Escovar-Fadul, X.; Nguyen, J.M.; Cadungog, M.G.; Zhang, R.; et al. Microbially driven TLR5-dependent signaling governs distal malignant progression through tumor-promoting inflammation. Cancer Cell. 2015, $27,27-40$.

20. Imani Fooladi, A.A.; Yazdi, M.H.; Pourmand, M.R.; Mirshafiey, A.; Hassan, Z.M.; Azizi, T.; Mahdavi, M.; Soltan Dallal, M.M. Th1 Cytokine Production Induced by Lactobacillus acidophilus in BALB/c Mice Bearing Transplanted Breast Tumor. Jundishapur J. Microbiol. 2015, 8, e17354. [CrossRef]

21. Turnbaugh, P.J.; Hamady, M.; Yatsunenko, T.; Cantarel, B.L.; Duncan, A.; Ley, R.E.; Sogin, M.L.; Jones, W.J.; Roe, B.A.; Affourtit, J.P.; et al. A core gut microbiome in obese and lean twins. Nature 2008, 457, 480. [CrossRef] [PubMed]

22. Morrison, D.J.; Preston, T. Formation of short chain fatty acids by the gut microbiota and their impact on human metabolism. Gut Microbes 2016, 7, 189-200. [CrossRef] [PubMed]

23. Regina Joice, K.Y.; Shafquat, A.; Xochitl, C.; Curtis Huttenhower, M. Determining microbial products and identifying molecular targets in the human microbiome. Cell Metab. 2014, 20, 731-741. [CrossRef] [PubMed]

24. Samuel, B.S.; Shaito, A.; Motoike, T.; Rey, F.E.; Backhed, F.; Manchester, J.K.; Hammer, R.E.; Williams, S.C.; Crowley, J.; Yanagisawa, M.; et al. Effects of the gut microbiota on host adiposity are modulated by the short-chain fatty-acid binding G protein-coupled receptor, Gpr41. Proc. Natl. Acad. Sci. USA 2008, 105, 16767-16772. [CrossRef]

25. Wang, H.; Altemus, J.; Niazi, F.; Green, H.; Calhoun, B.C.; Sturgis, C.; Grobmyer, S.R.; Eng, C. Breast tissue, oral and urinary microbiomes in breast cancer. Oncotarget 2017, 8, 88122-88138. [CrossRef]

26. Urbaniak, C.; Gloor, G.B.; Brackstone, M.; Scott, L.; Tangney, M.; Reid, G. The Microbiota of Breast Tissue and Its Association with Breast Cancer. Appl. Environ. Microbiol. 2016, 82, 5039-5048. [CrossRef]

27. Ghazalpour, A.; Cespedes, I.; Bennett, B.J.; Allayee, H. Expanding role of gut microbiota in lipid metabolism. Curr. Opin. Lipidol. 2016, 27, 141-147. [CrossRef]

28. Lee, I.O.; Kim, J.H.; Choi, Y.J.; Pillinger, M.H.; Kim, S.Y.; Blaser, M.J.; Lee, Y.C. Helicobacter pylori CagA phosphorylation status determines the gp130-activated SHP2/ERK and JAK/STAT signal transduction pathways in gastric epithelial cells. J. Biol Chem. 2010, 285, 16042-16050. [CrossRef]

29. Ojanotko-Harri, A.; Nikkari, T.; Harrl, M.-P.; Paunio, K. Metabolism of progesterone and testosterone by Bacillus cereus strain Socransky 67 and Streptococcus mutans strain Ingbritt. Oral. Microbiol. Immunol. 1990, 5, 237-239. [CrossRef]

30. Fulbright, L.E.; Ellermann, M.; Arthur, J.C. The microbiome and the hallmarks of cancer. PLoS Pathog. 2017, 13, e1006480. [CrossRef]

31. Tikkanen, M.J.; Adlercreutz, H.; Pulkkinen, M.O. Effects of antibiotics on oestrogen metabolism. Br. Med. J. 1973, 2, 369. [CrossRef] [PubMed]

32. Velicer, C.M.; Lampe, J.W.; Heckbert, S.R.; Potter, J.D.; Taplin, S.H. Hypothesis: Is antibiotic use associated with breast cancer? Cancer Causes Control.: CCC 2003, 14, 739-747. [CrossRef] [PubMed]

33. Velicer, C.M.; Heckbert, S.R.; Lampe, J.W.; Potter, J.D.; Robertson, C.A.; Taplin, S.H. Antibiotic Use in Relation to the Risk of Breast Cancer. JAMA 2004, 291, 827-835. [CrossRef] [PubMed] 
34. Friedman, G.D.; Oestreicher, N.; Chan, J.; Quesenberry, C.P., Jr.; Udaltsova, N.; Habel, L.A. Antibiotics and risk of breast cancer: Up to 9 years of follow-up of 2.1 million women. Cancer Epidemiol. Biomark. Prev. 2006, 15, 2102-2106. [CrossRef]

35. Velicer, C.M.; Heckbert, S.R.; Rutter, C.; Lampe, J.W.; Malone, K. Association between antibiotic use prior to breast cancer diagnosis and breast tumour characteristics (United States). Cancer Causes Control.: CCC 2006, 17, 307-313. [CrossRef] [PubMed]

36. Tamim, H.M.; Hanley, J.A.; Hajeer, A.H.; Boivin, J.F.; Collet, J.P. Risk of breast cancer in relation to antibiotic use. Pharmacoepidemiol. Drug Saf. 2008, 17, 144-150. [CrossRef]

37. Sergentanis, T.N.; Zagouri, F.; Zografos, G.C. Is antibiotic use a risk factor for breast cancer? A meta-analysis. Pharmacoepidemiol. Drug Saf. 2010, 19, 1101-1107. [CrossRef]

38. Wirtz, H.S.; Buist, D.S.M.; Gralow, J.R.; Barlow, W.E.; Gray, S.; Chubak, J.; Yu, O.; Bowles, E.J.A.; Fujii, M.; Boudreau, D.M. Frequent antibiotic use and second breast cancer events. Cancer Epidemiol. Biomark. Prev. 2013, 22, 1588-1599. [CrossRef]

39. Elkrief, A.; Derosa, L.; Kroemer, G.; Zitvogel, L.; Routy, B. The negative impact of antibiotics on outcomes in cancer patients treated with immunotherapy: A new independent prognostic factor? Ann. Oncol 2019, 30, 1572-1579. [CrossRef]

40. Urbaniak, C.; Cummins, J.; Brackstone, M.; Macklaim, J.M.; Gloor, G.B.; Baban, C.K.; Scott, L.; O’Hanlon, D.M.; Burton, J.P.; Francis, K.P.; et al. Microbiota of Human Breast Tissue. Appl. Environ. Microbiol. 2014, 80, 3007-3014. [CrossRef]

41. Chan, A.A.; Bashir, M.; Rivas, M.N.; Duvall, K.; Sieling, P.A.; Pieber, T.R.; Vaishampayan, P.A.; Love, S.M.; Lee, D.J. Characterization of the microbiome of nipple aspirate fluid of breast cancer survivors. Sci. Rep. 2016, 6, 28061. [CrossRef] [PubMed]

42. Hieken, T.J.; Chen, J.; Hoskin, T.L.; Walther-Antonio, M.; Johnson, S.; Ramaker, S.; Xiao, J.; Radisky, D.C.; Knutson, K.L.; Kalari, K.R.; et al. The Microbiome of Aseptically Collected Human Breast Tissue in Benign and Malignant Disease. Sci. Rep. 2016, 6, 30751. [CrossRef] [PubMed]

43. Costantini, L.; Magno, S.; Albanese, D.; Donati, C.; Molinari, R.; Filippone, A.; Masetti, R.; Merendino, N. Characterization of human breast tissue microbiota from core needle biopsies through the analysis of multi hypervariable 16S-rRNA gene regions. Sci. Rep. 2018, 8, 16893. [CrossRef] [PubMed]

44. Meng, S.; Chen, B.; Yang, J.; Wang, J.; Zhu, D.; Meng, Q.; Zhang, L. Study of Microbiomes in Aseptically Collected Samples of Human Breast Tissue Using Needle Biopsy and the Potential Role of in situ Tissue Microbiomes for Promoting Malignancy. Front. Oncol. 2018, 8, 318. [CrossRef]

45. Xuan, C.; Shamonki, J.M.; Chung, A.; Dinome, M.L.; Chung, M.; Sieling, P.A.; Lee, D.J. Microbial dysbiosis is associated with human breast cancer. PLoS ONE 2014, 9, e83744. [CrossRef]

46. Parida, S.; Sharma, D. The power of small changes: Comprehensive analyses of microbial dysbiosis in breast cancer. Biochim. Et Biophys. Acta. (BBA)—Rev. Cancer 2019, 1871, 392-405. [CrossRef]

47. Henley, S.J.; Ward, E.M.; Scott, S.; Ma, J.; Anderson, R.N.; Firth, A.U.; Thomas, C.C.; Islami, F.; Weir, H.K.; Lewis, D.R.; et al. Annual Report to the Nation on the Status of Cancer, part I: National cancer statistics. Cancer 2020. [CrossRef]

48. Henley, S.J.; Thomas, C.C.; Lewis, D.R.; Ward, E.M.; Islami, F.; Wu, M.; Weir, H.K.; Scott, S.; Sherman, R.L.; Ma, J.; et al. Annual Report to the Nation on the Status of Cancer, part II: Progress toward Healthy People 2020 objectives for 4 common cancers. Cancer 2020. [CrossRef]

49. DeSantis, C.E.; Ma, J.; Gaudet, M.M.; Newman, L.A.; Miller, K.D.; Goding Sauer, A.; Jemal, A.; Siegel, R.L. Breast cancer statistics, 2019. CA Cancer J. Clin. 2019, 69, 438-451. [CrossRef]

50. Gail, M.H.; Brinton, L.A.; Byar, D.P.; Corle, D.K.; Green, S.B.; Schairer, C.; Mulvihill, J.J. Projecting individualized probabilities of developing breast cancer for white females who are being examined annually. J. Natl. Cancer Inst. 1989, 81, 1879-1886. [CrossRef]

51. Petracci, E.; Decarli, A.; Schairer, C.; Pfeiffer, R.M.; Pee, D.; Masala, G.; Palli, D.; Gail, M.H. Risk factor modification and projections of absolute breast cancer risk. J. Natl. Cancer Inst. 2011, 103, 1037-1048. [CrossRef] [PubMed]

52. Decarli, A.; Calza, S.; Masala, G.; Specchia, C.; Palli, D.; Gail, M.H. Gail model for prediction of absolute risk of invasive breast cancer: Independent evaluation in the Florence-European Prospective Investigation Into Cancer and Nutrition cohort. J. Natl. Cancer Inst. 2006, 98, 1686-1693. [CrossRef] [PubMed] 
53. Banegas, M.P.; John, E.M.; Slattery, M.L.; Gomez, S.L.; Yu, M.; LaCroix, A.Z.; Pee, D.; Chlebowski, R.T.; Hines, L.M.; Thompson, C.A.; et al. Projecting Individualized Absolute Invasive Breast Cancer Risk in US Hispanic Women. J. Natl. Cancer Inst. 2017, 109. [CrossRef]

54. Gail, M.H.; Costantino, J.P.; Pee, D.; Bondy, M.; Newman, L.; Selvan, M.; Anderson, G.L.; Malone, K.E.; Marchbanks, P.A.; McCaskill-Stevens, W.; et al. Projecting individualized absolute invasive breast cancer risk in African American women. J. Natl. Cancer Inst. 2007, 99, 1782-1792. [CrossRef] [PubMed]

55. Costantino, J.P.; Gail, M.H.; Pee, D.; Anderson, S.; Redmond, C.K.; Benichou, J.; Wieand, H.S. Validation studies for models projecting the risk of invasive and total breast cancer incidence. J. Natl. Cancer Inst. 1999, 91, 1541-1548. [CrossRef] [PubMed]

56. Rockhill, B.; Spiegelman, D.; Byrne, C.; Hunter, D.J.; Colditz, G.A. Validation of the Gail et al. model of breast cancer risk prediction and implications for chemoprevention. J. Natl. Cancer Inst. 2001, 93, 358-366. [CrossRef]

57. Picon-Ruiz, M.; Morata-Tarifa, C.; Valle-Goffin, J.J.; Friedman, E.R.; Slingerland, J.M. Obesity and adverse breast cancer risk and outcome: Mechanistic insights and strategies for intervention. CA Cancer J. Clin. 2017, 67, 378-397. [CrossRef]

58. White, A.J.; Nichols, H.B.; Bradshaw, P.T.; Sandler, D.P. Overall and central adiposity and breast cancer risk in the Sister Study. Cancer 2015, 121, 3700-3708. [CrossRef]

59. Cotterchio, M.; Kreiger, N.; Theis, B.; Sloan, M.; Bahl, S. Hormonal Factors and the Risk of Breast Cancer According to Estrogen- and Progesterone-Receptor Subgroup. Cancer Epidemiol. Prev. Biomark. 2003, 12, 1053-1060.

60. Enger, S.M.; Ross, R.K.; Paganini-Hill, A.; Carpenter, C.L.; Bernstein, L. Body Size, Physical Activity, and Breast Cancer Hormone Receptor Status: Results from Two Case-Control Studies. Cancer Epidemiol. Prev. Biomark. 2000, 9, 681-687.

61. Neuhouser, M.L.; Aragaki, A.K.; Prentice, R.L.; Manson, J.E.; Chlebowski, R.; Carty, C.L.; Ochs-Balcom, H.M.; Thomson, C.A.; Caan, B.J.; Tinker, L.F.; et al. Overweight, Obesity, and Postmenopausal Invasive Breast Cancer Risk: A Secondary Analysis of the Women's Health Initiative Randomized Clinical Trials. JAMA Oncol. 2015, 1, 611-621. [CrossRef] [PubMed]

62. Suzuki, R.; Rylander-Rudqvist, T.; Ye, W.; Saji, S.; Wolk, A. Body weight and postmenopausal breast cancer risk defined by estrogen and progesterone receptor status among Swedish women: A prospective cohort study. Int. J. Cancer 2006, 119, 1683-1689. [CrossRef] [PubMed]

63. Ahn, J.; Schatzkin, A.; Lacey, J.V., Jr.; Albanes, D.; Ballard-Barbash, R.; Adams, K.F.; Kipnis, V.; Mouw, T.; Hollenbeck, A.R.; Leitzmann, M.F. Adiposity, Adult Weight Change, and Postmenopausal Breast Cancer Risk. Arch. Intern. Med. 2007, 167, 2091-2102. [CrossRef] [PubMed]

64. Setiawan, V.W.; Monroe, K.R.; Wilkens, L.R.; Kolonel, L.N.; Pike, M.C.; Henderson, B.E. Breast cancer risk factors defined by estrogen and progesterone receptor status: The multiethnic cohort study. Am. J. Epidemiol. 2009, 169, 1251-1259. [CrossRef]

65. Rosenberg, L.U.; Einarsdóttir, K.; Friman, E.I.; Wedrén, S.; Dickman, P.W.; Hall, P.; Magnusson, C. Risk Factors for Hormone Receptor-Defined Breast Cancer in Postmenopausal Women. Cancer Epidemiol. Biomarkers Prev. 2006, 15, 2482-2488. [CrossRef]

66. Phipps, A.I.; Chlebowski, R.T.; Prentice, R.; McTiernan, A.; Stefanick, M.L.; Wactawski-Wende, J.; Kuller, L.H.; Adams-Campbell, L.L.; Lane, D.; Vitolins, M.; et al. Body size, physical activity, and risk of triple-negative and estrogen receptor-positive breast cancer. Cancer Epidemiol. Biomark. Prev. 2011, 20, 454-463. [CrossRef]

67. John, E.M.; Sangaramoorthy, M.; Hines, L.M.; Stern, M.C.; Baumgartner, K.B.; Giuliano, A.R.; Wolff, R.K.; Slattery, M.L. Body size throughout adult life influences postmenopausal breast cancer risk among hispanic women: The breast cancer health disparities study. Cancer Epidemiol. Biomark. Prev. 2015, 24, 128-137. [CrossRef]

68. Michels, K.B.; Terry, K.L.; Willett, W.C. Longitudinal Study on the Role of Body Size in Premenopausal Breast Cancer. Arch. Intern. Med. 2006, 166, 2395-2402. [CrossRef]

69. Berstad, P.; Coates, R.J.; Bernstein, L.; Folger, S.G.; Malone, K.E.; Marchbanks, P.A.; Weiss, L.K.; Liff, J.M.; McDonald, J.A.; Strom, B.L.; et al. A case-control study of body mass index and breast cancer risk in white and African-American women. Cancer Epidemiol. Biomark. Prev. 2010, 19, 1532-1544. [CrossRef]

70. Harris, H.R.; Willett, W.C.; Terry, K.L.; Michels, K.B. Body fat distribution and risk of premenopausal breast cancer in the Nurses' Health Study II. J. Natl. Cancer Inst. 2011, 103, 273-278. [CrossRef] 
71. Chang, S.; Buzdar, A.U.; Hursting, S.D. Inflammatory breast cancer and body mass index. J. Clin. Oncol. 1998, 16, 3731-3735. [CrossRef]

72. Hooper, L.V.; Midtvedt, T.; Gordon, J. How host-microbial interactions shape the nutrient environment of the mammalian intestine. Annu Rev. Nutr 2002, 22, 283-307. [CrossRef]

73. Brown, A.J.; Goldsworthy, S.M.; Barnest, A.A.; Eilert, M.M.; Tcheangt, L.; Daniels, D.; Muir, A.I.; Wigglesworth, M.J.; Kinghorn, I.; Fraser, N.J.; et al. The Orphan G Protein-coupled Receptors GPR41 and GPR43 Are Activated by Propionate and Other Short Chain Carboxylic Acids. J. Biol. Chem. 2003, 278, 11312-11319. [CrossRef] [PubMed]

74. Le Roux, C.W.; Bloom, S.R. Peptide YY, appetite and food intake. Proc. Nutr. Soc. 2005, 64, 213-216. [CrossRef]

75. Hullar, M.A.; Fu, B.C. Diet, the gut microbiome, and epigenetics. Cancer J. (SudburyMass) 2014, $20,170$. [CrossRef] [PubMed]

76. Louis, P.; Flint, H.J. Diversity, metabolism and microbial ecology of butyrate-producing bacteria from the human large intestine. FEMS Microbiol Lett 2009, 294, 1-8. [CrossRef] [PubMed]

77. Million, M.; Lagier, J.C.; Yahav, D.; Paul, M. Gut bacterial microbiota and obesity. Clin. Microbiol. Infect. 2013, 19, 305-313. [CrossRef] [PubMed]

78. Loscalzo, J. Lipid metabolism by gut microbes and atherosclerosis. Circ Res. 2011, 109, 127-129. [CrossRef]

79. Ley, R.E.; Bäckhed, F.; Turnbaugh, P.J.; Lozupone, C.A.; Knight, R.D.; Gordon, J.I. Obesity alters gut microbial ecology. Proc. Natl. Acad. Sci. USA 2005, 102, 11070-11075. [CrossRef]

80. Isaac, T.W.; Harley, C.L.K. Obesity and the gut microbiome: Striving for causality. Mol. Metab. 2012, 1, $21-31$.

81. Zheng, J.; Gänzle, M.G.; Lin, X.B.; Ruan, L.; Sun, M. Diversity and dynamics of bacteriocins from human microbiome. Environ Microbiol. 2015, 17, 2133-2143. [CrossRef] [PubMed]

82. Gui, Y.; Pan, Q.; Chen, X.; Xu, S.; Luo, X.; Chen, L. The association between obesity related adipokines and risk of breast cancer: A meta-analysis. Oncotarget 2017, 8, 75389-75399. [CrossRef] [PubMed]

83. Cani, P.D.; Possemiers, S.; Van de Wiele, T.; Guiot, Y.; Everard, A.; Rottier, O.; Geurts, L.; Naslain, D.; Neyrinck, A.; Lambert, D.M.; et al. Changes in gut microbiota control inflammation in obese mice through a mechanism involving GLP-2-driven improvement of gut permeability. Gut 2009, 58, 1091-1103. [CrossRef] [PubMed]

84. Vieira, S.; Pagovich, O.; Kriegel, M. Diet, microbiota and autoimmune diseases. Lupus 2014, 23, 518-526. [CrossRef]

85. Turnbaugh, P.J.; Ridaura, V.K.; Faith, J.J.; Rey, F.E.; Knight, R.; Gordon, J.I. The Effect of Diet on the Human Gut Microbiome: A Metagenomic Analysis in Humanized Gnotobiotic Mice. Sci. Transl. Med. 2009, 1, ra14-ra16. [CrossRef]

86. Paul, B.; Barnes, S.; Demark-Wahnefried, W.; Morrow, C.; Salvador, C.; Skibola, C.; Tollefsbol, T.O. Influences of diet and the gut microbiome on epigenetic modulation in cancer and other diseases. Clin. Epigenetics 2015, 7, 112. [CrossRef]

87. Turnbaugh, P.J.; Ley, R.E.; Mahowald, M.A.; Magrini, V.; Mardis, E.R.; Gordon, J.I. An obesity associated gut microbiome with increased capacity for energy harvest. Nature 2006, 444, 1027-1031. [CrossRef]

88. Ridlon, J.M.; Kang, D.J.; Hylemon, P.B.; Bajaj, J.S. Bile Acids and the Gut Microbiome. Curr. Opin. Gastroenterol. 2014, 30, 332-338.

89. Takahashi, K.; Sugi, Y.; Nakano, K.; Tsuda, M.; Kurihara, K.; Hosono, A. Epigenetic control of the host gene by commensal bacteria in large intestinal epithelial cells. J. Biol. Chem. 2011, 286, 35755-35762. [CrossRef]

90. Berni Canani, R.; Di Costanzo, M.; Leone, L. The epigenetic effects of butyrate: Potential therapeutic implications for clinical practice. Clin. Epigenetics 2012, 4, 4. [CrossRef]

91. Pompei, A.; Cordisco, L.; Amaretti, A.; Zanoni, S.; Matteuzzi, D.; Rossi, M. Folate Production by Bifidobacteria as a Potential Probiotic Property. Appl. Environ. Microbiol. 2007, 73, 179-185. [CrossRef] [PubMed]

92. Samsel, A.; Seneff, S. Glyphosate's Suppression of Cytochrome P450 Enzymes and Amino Acid Biosynthesis by the Gut Microbiome: Pathways to Modern Diseases. Entropy 2013, 15, 1416-1463. [CrossRef]

93. Shenderov, B.A. Gut indigenous microbiota and epigenetics. Microb. Ecol. Health Dis. 2012, 23. [CrossRef] [PubMed]

94. Huda-Faujan, N.; Abdulamir, A.S.; Fatimah, A.B.; Anas, O.M.; Shuhaimi, M.; Yazid, A.M.; Loong, Y.Y. The Impact of the Level of the Intestinal Short Chain Fatty Acids in Inflammatory Bowel Disease Patients Versus Healthy Subjects. Open Biochem. J. 2010, 4, 53-58. [CrossRef] 
95. Ghanim, H.; Abuaysheh, S.; Sia, C.L.; Korzeniewski, K.; Chaudhuri, A.; Fernandez-Real, J.M.; Dandona, P. Increase in plasma endotoxin concentrations and the expression of Toll-like receptors and suppressor of cytokine signaling-3 in mononuclear cells after a high-fat, high-carbohydrate meal: Implications for insulin resistance. Diabetes Care. 2009, 32, 2281-2287.

96. Takahashi, K. Influence of bacteria on epigenetic gene control. Cell Mol. Life Sci. 2014, 71, $1045-1054$. [CrossRef]

97. Davie, J.R. Inhibition of Histone Deacetylase Activity by Butyrate. J. Nutr. 2003, 133, 2485S-2493S. [CrossRef]

98. Hýzd'alova, M.; Hofmanova, J.; Pachermk, J.; Vaculova, A.; Kozubik, A. The interaction of butyrate with TNF-a during differentiation and apoptosis of colon epithelial cells: Role of NF-k B activation. Cytokine 2008, 44, 33-43. [CrossRef]

99. Koeth, R.A.; Wang, Z.; Levison, B.S.; Buffa, J.A.; Org, E.; Sheehy, B.T.; Britt, E.B.; Fu, X.; Wu, Y.; Li, L.; et al. Intestinal microbiota metabolism of l-carnitine, a nutrient in red meat, promotes atherosclerosis. Nat. Med. 2013, 19, 576. [CrossRef]

100. Selkrig, J.; Wong, P.; Zhang, X.; Pettersson, S. Metabolic tinkering by the gut microbiome: Implications for brain development and function. Gut Microbes 2014, 5, 369-380. [CrossRef]

101. Donohoe, D.R.; Garge, N.; Zhang, X.; Sun, W.; O'Connell, T.M.; Bunger, M.K. The microbiome and butyrate regulate energy metabolism and autophagy in the mammalian colon. Cell Metab. 2011, 13, 517-526. [CrossRef] [PubMed]

102. Duggal, P.; Guo, X.; Haque, R.; Peterson, K.M.; Ricklefs, S.; Mondal, D.; Alam, F.; Noor, Z.; Verkerke, H.P.; Marie, C.; et al. A mutation in the leptin receptor is associated with Entamoeba histolytica infection in children. J. Clin. Investig. 2011, 121, 1191-1198. [CrossRef] [PubMed]

103. Vieira, A.T.; Macia, L.; Galvão, I.; Martins, F.S.; Canesso, M.C.; Amaral, F.A. A role for gut microbiota and the metabolite-sensing receptor GPR43 in a murine model of gout. Arthritis Rheumatol. 2015, 67, 1646-1656. [CrossRef] [PubMed]

104. Hague, A.; Manning, A.M.; Hanlon, K.A.; Hart, D.; Paraskeva, C.; Huschtscha, L.I. Sodium butyrate induces apoptosis in human colonic tumour cell lines in a p53-independent pathway: Implications for the possible role of dietary fibre in the prevention of large-bowel cancer. Int. J. Cancer 1993, 55, 498-505. [CrossRef] [PubMed]

105. Candido, E.P.M.; Reeves, R.; Davie, J.R. Sodium butyrate inhibits histone deacetylation in cultured cells. Get Cell 1978, 14, 105-113. [CrossRef]

106. Sharon, G.; Garg, N.; Debelius, J.; Knight, R.; Dorrestein, P.C.; Mazmanian, S.K. Specialized Metabolites from the Microbiome in Health and Disease. Cell Metab. 2014, 20, 719-730. [CrossRef]

107. Hesson, L.B. Gut microbiota and obesity-related gastrointestinal cancer: A focus on epigenetics. Trans. Gastrointest Cancer 2013, 2, 204-210.

108. Ley, R.E.; Turnbaugh, P.J.; S, K.; Gordon, J. Microbial ecology:human gut microbes associated with obesity. Nature 2006, 444, 1022-1023. [CrossRef]

109. Ley, R.E. Obesity and the human microbiome. Curr. Opin. Gastroenterol. 2010, 26, 5-11. [CrossRef]

110. Rosa, B.A.; Hallsworth-Pepin, K.; Martin, J.; Wollam, A.; Mitreva, M. Genome Sequence of Christensenella minuta DSM 22607T. Genome Announc 2017, 5, e01416-e01451. [CrossRef]

111. Arumugam, M.; Raes, J.; Pelletier, E.; Le Paslier, D.; Yamada, T.; Mende, D.R.; Fernandes, G.R.; Tap, J.; Bruls, T.; Batto, J.M.; et al. Enterotypes of the human gut microbiome. Nature 2011, 473, 174-180. [CrossRef] [PubMed]

112. Mai, V.; McCrary, Q.M.; Sinha, R.; Glei, M. Associations between dietary habits and body mass index with gut microbiota composition and fecal water genotoxicity: An observational study in African American and Caucasian American volunteers. Nutr. J. 2009, 8, 49. [CrossRef] [PubMed]

113. Million, M.; Maraninchi, M.; Henry, M.; Armougom, F.; Richet, H.; Carrieri, P.; Valero, R.; Raccah, D.; Vialettes, B.; Raoult, D. Obesity-associated gut microbiota is enriched in Lactobacillus reuteri and depleted in Bifidobacterium animalis and Methanobrevibacter smithii. Int. J. Obes. 2011, 36, 817. [CrossRef] [PubMed]

114. Jeffery, I.B.; O'Toole, P.W. Diet-microbiota interactions and their implications for healthy living. Nutrients 2013, 5, 234-252. [CrossRef] [PubMed]

115. Hu, S.; Dong, T.S.; Dalal, S.R.; Wu, F.; Bissonnette, M.; Kwon, J.H.; Chang, E.B. The microbe-derived short chain fatty acid butyrate targets miRNA-dependent p21 gene expression in human colon cancer. PLoS ONE 2011, 6, e16221. [CrossRef] [PubMed] 
116. Xiong, Y.; Miyamoto, N.; Shibata, K.; Valasek, M.A.; Motoike, T.; Kedzierski, R.M.; Yanagisawa, M. Short-chain fatty acids stimulate leptin production in adipocytes through the $\mathrm{G}$ protein-coupled receptor GPR41. Proc. Natl. Acad. Sci. USA 2004, 101, 1045-1050. [CrossRef]

117. Khan, M.J.; Gerasimidis, K.; Edwards, C.A.; Shaikh, M.G. Role of gut microbiota in the aetiology of obesity: Proposed mechanisms and review of the literature. J. Obes. 2016. [CrossRef]

118. Bäckhed, F.; Ding, H.; Wang, T.; Hooper, L.V.; Koh, G.Y.; Nagy, A.; Semenkovich, C.F.; Gordon, J.I. The gut microbiota as an environmental factor that regulates fat storage. Proc. Natl. Acad. Sci. USA 2004, 101, 15718-15723. [CrossRef]

119. Stappenbeck, T.S.; Hooper, L.V.; Gordon, J.I. Developmental regulation of intestinal angiogenesis by indigenous microbes via Paneth cells. Proc. Natl. Acad. Sci. USA 2002, 99, 15451-15455. [CrossRef]

120. Hooper, L.V.; Wong, M.H.; Thelin, A.; Hansson, L.; Falk, P.G.; Gordon, J.I. Molecular Analysis of Commensal Host-Microbial Relationships in the Intestine. Science 2001, 291, 881-884. [CrossRef] [PubMed]

121. Plaza-Díaz, J.; Álvarez-Mercado, A.I.; Ruiz-Marín, C.M.; Reina-Pérez, I.; Pérez-Alonso, A.J.; Sánchez-Andujar, M.B.; Torné, P.; Gallart-Aragón, T.; Sánchez-Barrón, M.T.; Reyes Lartategui, S.; et al. Association of breast and gut microbiota dysbiosis and the risk of breast cancer: A case-control clinical study. BMC Cancer 2019, 19, 495. [CrossRef] [PubMed]

122. Bradlow, H.L. Obesity and the gut microbiome: Pathophysiological aspects. Horm. Mol. Biol. Clin. Investig. 2014, 17, 53-61. [CrossRef] [PubMed]

123. Frugé, A.D.; Van der Pol, W.; Rogers, L.Q.; Morrow, C.D.; Tsuruta, Y.; Demark-Wahnefried, W. Fecal Akkermansia muciniphila Is Associated with Body Composition and Microbiota Diversity in Overweight and Obese Women with Breast Cancer Participating in a Presurgical Weight Loss Trial. J. Acad. Nutr. Diet. 2020, 120, 650-659. [CrossRef]

124. Quong, J.; Eppenberger-Castori, S.; Moore, D., 3rd; Scott, G.K.; Birrer, M.J.; Kueng, W.; Eppenberger, U.; Benz, C.C. Age-dependent changes in breast cancer hormone receptors and oxidant stress markers. Breast Cancer Res. Treat. 2002, 76, 221-236. [CrossRef]

125. Benz, C.C. Impact of aging on the biology of breast cancer. Crit. Rev. Oncol. Hematol. 2008, 66, 65-74. [CrossRef] [PubMed]

126. Lodi, M.; Scheer, L.; Reix, N.; Heitz, D.; Carin, A.J.; Thiebaut, N.; Neuberger, K.; Tomasetto, C.; Mathelin, C. Breast cancer in elderly women and altered clinico-pathological characteristics: A systematic review. Breast Cancer Res. Treat. 2017, 166, 657-668. [CrossRef]

127. Thongaram, T.; Hoeflinger, J.L.; Chow, J.; Miller, M.J. Human milk oligosaccharide consumption by probiotic and human-associated bifidobacteria and lactobacilli. J. Dairy Sci. 2017, 100, 7825-7833. [CrossRef]

128. Goldsmith, F.; O'Sullivan, A.; Smilowitz, J.T.; Freeman, S.L. Lactation and Intestinal Microbiota: How Early Diet Shapes the Infant Gut. J. Mammary Gland Biol. Neoplasia 2015, 20, 149-158. [CrossRef]

129. Mariat, D.; Firmesse, O.; Levenez, F.; Guimarăes, V.; Sokol, H.; Doré, J.; Corthier, G.; Furet, J.P. The Firmicutes/Bacteroidetes ratio of the human microbiota changes with age. BMC Microbiol. 2009, 9, 123. [CrossRef]

130. Reddy, B.S.; Rivenson, A. Inhibitory Effect of Bifidobacterium longum on Colon, Mammary, and Liver Carcinogenesis Induced by 2-Amino-3-methylimidazo[4,5-]quinoline, a Food Mutagen. Cancer Res. 1993, 53, 3914-3918.

131. Biffi, A.; Coradini, D.; Larsen, R.; Riva, L.; Di Fronzo, G. Antiproliferative effect of fermented milk on the growth of a human breast cancer cell line. Nutr. Cancer 1997, 28, 93-99. [CrossRef] [PubMed]

132. Orrhage, K.; Nord, C.E. Bifidobacteria and lactobacilli in human health. Drugs Exp Clin Res. 2000, $26,95-111$. [PubMed]

133. Dinan, T.G.; Cryan, J.F. Gut instincts: Microbiota as a key regulator of brain development, ageing and neurodegeneration. J. Physiol. 2017, 595, 489-503. [CrossRef] [PubMed]

134. Flint, H.J. Gut microbial metabolites in health and disease. Gut Microbes 2016, 7, 187-188. [CrossRef]

135. Zapata, H.J.; Quagliarello, V.J. The microbiota and microbiome in aging: Potential implications in health and age-related diseases. J. Am. Geriatr. Soc. 2015, 63, 776-781. [CrossRef]

136. Vaiserman, A.M.; Koliada, A.K.; Marotta, F. Gut microbiota: A player in aging and a target for anti-aging intervention. Ageing Res. Rev. 2017, 35, 36-45. [CrossRef] 
137. Landete, J.M.; Gaya, P.; Rodríguez, E.; Langa, S.; Peirotén, Á.; Medina, M.; Arqués, J.L. Probiotic Bacteria for Healthier Aging: Immunomodulation and Metabolism of Phytoestrogens. BioMed Res. Int. 2017, 2017, 5939818. [CrossRef]

138. Key, T.; Appleby, P.; Barnes, I.; Reeves, G.; Endogenous, H.; Endogenous Hormones and Breast Cancer Collaborative Group. Endogenous sex hormones and breast cancer in postmenopausal women: Reanalysis of nine prospective studies. J. Natl. Cancer Inst. 2002, 94, 606-616.

139. Breast cancer and hormone replacement therapy: Collaborative reanalysis of data from 51 epidemiological studies of 52,705 women with breast cancer and 108,411 women without breast cancer. Collaborative Group on Hormonal Factors in Breast Cancer. Lancet 1997, 350, 1047-1059.

140. Hamajima, N.; Hirose, K.; Tajima, K.; Rohan, T.; Calle, E.E.; Heath, C.W., Jr.; Coates, R.J.; Liff, J.M.; Talamini, R.; Chantarakul, N.; et al. Alcohol, tobacco and breast cancer-collaborative reanalysis of individual data from 53 epidemiological studies, including 58,515 women with breast cancer and 95,067 women without the disease. Br. J. Cancer 2002, 87, 1234-1245.

141. Dorgan, J.F.; Baer, D.J.; Albert, P.S.; Judd, J.T.; Brown, E.D.; Corle, D.K.; Campbell, W.S.; Hartman, T.J.; Tejpar, A.A.; Clevidence, B.A.; et al. Serum hormones and the alcohol-breast cancer association in postmenopausal women. J. Natl. Cancer Inst. 2001, 93, 710-715. [CrossRef]

142. Vainio, H.; Kaaks, R.; Bianchini, F. Weight control and physical activity in cancer prevention: International evaluation of the evidence. Eur. J. Cancer Prev. 2002, 11, S94-S100.

143. Stone, S.A.; Han, C.J.; Senn, T.; Korde, L.A.; Allott, K.; Reding, S.; Whittington, D.; Reding, K.W. Sex Hormones in Women With Elevated Breast Cancer Risk Undergoing Weight Loss. West. J. Nurs Res. 2019, 41, 1602-1622. [CrossRef]

144. Plottel, C.S.; Blaser, M.J. Microbiome and Malignancy. Cell Host Microbe 2011, 10, 324-335. [CrossRef] [PubMed]

145. Parida, S.; Sharma, D. The Microbiome-Estrogen Connection and Breast Cancer Risk. Cells 2019, 8, 1642. [CrossRef] [PubMed]

146. Landete, J.M.; Arqués, J.; Medina, M.; Gaya, P.; de Las Rivas, B.; Muñoz, R. Bioactivation of Phytoestrogens: Intestinal Bacteria and Health. Crit. Rev. Food Sci. Nutr. 2016, 56, 1826-1843. [CrossRef]

147. Fuhrman, B.J.; Feigelson, H.S.; Flores, R.; Gail, M.H.; Xu, X.; Ravel, J.; Goedert, J.J. Associations of the fecal microbiome with urinary estrogens and estrogen metabolites in postmenopausal women. J. Clin. Endocrinol. Metab 2014, 99, 4632-4640. [CrossRef] [PubMed]

148. Fuhrman, B.J.; Schairer, C.; Gail, M.H.; Boyd-Morin, J.; Xu, X.; Sue, L.Y.; Buys, S.S.; Isaacs, C.; Keefer, L.K.; Veenstra, T.D.; et al. Estrogen metabolism and risk of breast cancer in postmenopausal women. J. Natl. Cancer Inst. 2012, 104, 326-339. [CrossRef] [PubMed]

149. Flores, R.; Shi, J.; Fuhrman, B.; Xu, X.; Veenstra, T.D.; Gail, M.H.; Gajer, P.; Ravel, J.; Goedert, J.J. Fecal microbial determinants of fecal and systemic estrogens and estrogen metabolites: A cross-sectional study. J. Transl. Med. 2012, 10, 253. [CrossRef]

150. Goedert, J.J.; Jones, G.; Hua, X.; Xu, X.; Yu, G.; Flores, R.; Falk, R.T.; Gail, M.H.; Shi, J.; Ravel, J.; et al. Investigation of the association between the fecal microbiota and breast cancer in postmenopausal women: A population-based case-control pilot study. J. Natl. Cancer Inst. 2015, 107, djv147. [CrossRef]

151. Shao, J.; Wu, L.; Leng, W.-D.; Fang, C.; Zhu, Y.-J.; Jin, Y.-H.; Zeng, X.-T. Periodontal Disease and Breast Cancer: A Meta-Analysis of 1,73,162 Participants. Front. Oncol. 2018, 8, 601. [CrossRef]

152. Freudenheim, J.L.; Genco, R.J.; LaMonte, M.J.; Millen, A.E.; Hovey, K.M.; Mai, X.; Nwizu, N.; Andrews, C.A.; Wactawski-Wende, J. Periodontal Disease and Breast Cancer: Prospective Cohort Study of Postmenopausal Women. Cancer Epidemiol. Biomark. Prev. 2016, 25, 43-50. [CrossRef]

153. Mai, X.; LaMonte, M.J.; Hovey, K.M.; Freudenheim, J.L.; Andrews, C.A.; Genco, R.J.; Wactawski-Wende, J. Periodontal disease severity and cancer risk in postmenopausal women: The Buffalo OsteoPerio Study. Cancer Causes Control. 2016, 27, 217-228. [CrossRef]

154. Nwizu, N.N.; Marshall, J.R.; Moysich, K.; Genco, R.J.; Hovey, K.M.; Mai, X.; LaMonte, M.J.; Freudenheim, J.L.; Wactawski-Wende, J. Periodontal Disease and Incident Cancer Risk among Postmenopausal Women: Results from the Women's Health Initiative Observational Cohort. Cancer Epidemiol. Biomark. Prev. 2017, 26, 1255-1265. [CrossRef] [PubMed] 
155. Camila, S.; SfreddoDizdar, O.; Hayran, M.; Guven, D.C.; Yılmaz, T.B.; Taheri, S.; Akman, A.C.; Bilgin, E.; Hüseyin, B.; Berker, E. Increased cancer risk in patients with periodontitis. Curr. Med. Res. Opin. 2017, 33, 2195-2200.

156. Sfreddo, C.S.; Maier, J.; De David, S.C.; Susin, C.; Moreira, C.H.C. Periodontitis and breast cancer: A case-control study. Community Dent. Oral Epidemiol. 2017, 45, 545-551. [CrossRef] [PubMed]

157. Miller, M.B.; Bassler, B.L. Quorum Sensing in Bacteria. Annu. Rev. Microbiol. 2001, 55, 165-199. [CrossRef] [PubMed]

158. Urbaniak, C.; Gloor, G.; Brackstone, M.; Tangney, M.; Reid, G. The microbiota of breast tissue and its association with tumours. Appl. Environ. Microbiol. 2016, 82, 5039-5048. [CrossRef]

159. Cardona, F.; Andrés-Lacueva, C.; Tulipani, S.; Tinahones, F.J.; Queipo-Ortuño, M.I. Benefits of polyphenols on gut microbiota and implications in human health. J. Nutr. Biochem. 2013, 24, 1415-1422. [CrossRef]

160. Kang, J.D.; Myers, C.J.; Harris, S.C.; Kakiyama, G.; Lee, I.-K.; Yun, B.-S.; Matsuzaki, K.; Furukawa, M.; Min, H.-K.; Bajaj, J.S.; et al. Bile Acid $7 \alpha$-Dehydroxylating Gut Bacteria Secrete Antibiotics that Inhibit Clostridium difficile: Role of Secondary Bile Acids. Cell Chem. Biol. 2019, 26, 27-34.e24. [CrossRef]

161. Ndeh, D.; Rogowski, A.; Cartmell, A.; Luis, A.S.; Baslé, A.; Gray, J.; Venditto, I.; Briggs, J.; Zhang, X.; Labourel, A.; et al. Complex pectin metabolism by gut bacteria reveals novel catalytic functions. Nature 2017, 544, 65-70. [CrossRef] [PubMed]

162. Pan, W.-H.; Sommer, F.; Falk-Paulsen, M.; Ulas, T.; Best, P.; Fazio, A.; Kachroo, P.; Luzius, A.; Jentzsch, M.; Rehman, A.; et al. Exposure to the gut microbiota drives distinct methylome and transcriptome changes in intestinal epithelial cells during postnatal development. Genome Med. 2018, 10, 27. [CrossRef] [PubMed]

163. Flint, H.J.; Scott, K.P.; Duncan, S.H.; Louis, P.; Forano, E. Microbial degradation of complex carbohydrates in the gut. Gut Microbes 2012, 3, 289-306. [CrossRef] [PubMed]

164. Hill, M.J. The role of colon anaerobes in the metabolism of bile acids and steroids, and its relation to colon cancer. Cancer 1975, 36, 2387-2400. [CrossRef]

165. LeBlanc, J.G.; Milani, C.; de Giori, G.S.; Sesma, F.; van Sinderen, D.; Ventura, M. Bacteria as vitamin suppliers to their host: A gut microbiota perspective. Curr. Opin. Biotechnol. 2013, 24, 160-168. [CrossRef]

166. Rowland, I.; Gibson, G.; Heinken, A.; Scott, K.; Swann, J.; Thiele, I.; Tuohy, K. Gut microbiota functions: Metabolism of nutrients and other food components. Eur. J. Nutr. 2018, 57, 1-24. [CrossRef]

167. Feng, X.; Li, Y.; Brobbey Oppong, M.; Qiu, F. Insights into the intestinal bacterial metabolism of flavonoids and the bioactivities of their microbe-derived ring cleavage metabolites. Drug Metab. Rev. 2018, 50, 343-356. [CrossRef]

168. Tailford, L.E.; Crost, E.H.; Kavanaugh, D.; Juge, N. Mucin glycan foraging in the human gut microbiome. Front. Genet. 2015, 6, 81. [CrossRef]

169. Geller, L.T.; Barzily-Rokni, M.; Danino, T.; Jonas, O.H.; Shental, N.; Nejman, D.; Gavert, N.; Zwang, Y.; Cooper, Z.A.; Shee, K.; et al. Potential role of intratumor bacteria in mediating tumor resistance to the chemotherapeutic drug gemcitabine. Science 2017, 357, 1156-1160. [CrossRef]

170. Urdaneta, V.; Casadesús, J. Interactions between Bacteria and Bile Salts in the Gastrointestinal and Hepatobiliary Tracts. Front. Med. 2017, 4, 163. [CrossRef]

171. Laparra, J.M.; Sanz, Y. Interactions of gut microbiota with functional food components and nutraceuticals. Pharmacol. Res. 2010, 61, 219-225. [CrossRef] [PubMed]

172. Madsen, L.; Myrmel, L.S.; Fjære, E.; Liaset, B.; Kristiansen, K. Links between Dietary Protein Sources, the Gut Microbiota, and Obesity. Front. Physiol. 2017, 8, 1047. [CrossRef] [PubMed]

173. Van Duynhoven, J.; Vaughan, E.E.; Jacobs, D.M.; Kemperman, A.R.; van Velzen, E.J.J.; Gross, G.; Roger, L.C.; Possemiers, S.; Smilde, A.K.; Doré, J.; et al. Metabolic fate of polyphenols in the human superorganism. Proc. Natl. Acad. Sci. USA 2011, 108, 4531-4538. [CrossRef] [PubMed]

174. Zipperer, A.; Konnerth, M.C.; Laux, C.; Berscheid, A.; Janek, D.; Weidenmaier, C.; Burian, M.; Schilling, N.A.; Slavetinsky, C.; Marschal, M.; et al. Human commensals producing a novel antibiotic impair pathogen colonization. Nature 2016, 535, 511. [CrossRef] [PubMed]

175. Mamo, G. Anaerobes as Sources of Bioactive Compounds and Health Promoting Tools. In Anaerobes in Biotechnology; Hatti-Kaul, R., Mamo, G., Mattiasson, B., Eds.; Springer International Publishing: Cham, Switzerland, 2016; pp. 433-464. 
176. Furusawa, Y.; Obata, Y.; Fukuda, S.; Endo, T.A.; Nakato, G.; Takahashi, D.; Nakanishi, Y.; Uetake, C.; Kato, K.; Kato, T.; et al. Commensal microbe-derived butyrate induces the differentiation of colonic regulatory $\mathrm{T}$ cells. Nature 2013, 504, 446. [CrossRef] [PubMed]

177. Smith, P.M.; Howitt, M.R.; Panikov, N.; Michaud, M.; Gallini, C.A.; Bohlooly-Y, M.; Glickman, J.N.; Garrett, W.S. The Microbial Metabolites, Short-Chain Fatty Acids, Regulate Colonic Treg Cell Homeostasis. Science 2013, 341, 569-573. [CrossRef]

178. Shibata, N.; Kunisawa, J.; Kiyono, H. Dietary and Microbial Metabolites in the Regulation of Host Immunity. Front. Microbiol. 2017, 8, 2171. [CrossRef]

179. Levy, M.; Thaiss, C.A.; Elinav, E. Metabolites: Messengers between the microbiota and the immune system. Genes Dev. 2016, 30, 1589-1597. [CrossRef]

180. Postler, T.S.; Ghosh, S. Understanding the Holobiont: How Microbial Metabolites Affect Human Health and Shape the Immune System. Cell Metab. 2017, 26, 110-130. [CrossRef]

181. Thirunavukkarasan, M.; Wang, C.; Rao, A.; Hind, T.; Teo, Y.R.; Siddiquee, A.A.-M.; Goghari, M.A.I.; Kumar, A.P.; Herr, D.R. Short-chain fatty acid receptors inhibit invasive phenotypes in breast cancer cells. PLoS ONE 2017, 12, e0186334. [CrossRef]

182. Elangovan, S.; Pathania, R.; Ramachandran, S.; Ananth, S.; Padia, R.N.; Lan, L.; Singh, N.; Martin, P.M.; Hawthorn, L.; Prasad, P.D.; et al. The Niacin/Butyrate Receptor GPR109A Suppresses Mammary Tumorigenesis by Inhibiting Cell Survival. Cancer Res. 2014, 74, 1166-1178. [CrossRef] [PubMed]

183. Schug, Z.T.; Vande Voorde, J.; Gottlieb, E. The metabolic fate of acetate in cancer. Nat. Rev. Cancer 2016, 16, 708. [CrossRef] [PubMed]

184. Puccetti, P.; Fallarino, F.; Italiano, A.; Soubeyran, I.; MacGrogan, G.; Debled, M.; Velasco, V.; Bodet, D.; Eimer, S.; Veldhoen, M.; et al. Accumulation of an Endogenous Tryptophan-Derived Metabolite in Colorectal and Breast Cancers. PLoS ONE 2015, 10, e0122046. [CrossRef]

185. Dewi, D.L.; Mohapatra, S.R.; Blanco Cabañes, S.; Adam, I.; Somarribas Patterson, L.F.; Berdel, B.; Kahloon, M.; Thürmann, L.; Loth, S.; Heilmann, K.; et al. Suppression of indoleamine-2,3-dioxygenase 1 expression by promoter hypermethylation in ER-positive breast cancer. OncoImmunology 2017, 6, e1274477. [CrossRef]

186. Cao, Z.-G.; Qin, X.-B.; Liu, F.-F.; Zhou, L.-L. Tryptophan-induced pathogenesis of breast cancer. Afr. Health Sci. 2015, 15, 982-985. [CrossRef] [PubMed]

187. Bekki, K.; Vogel, H.; Li, W.; Ito, T.; Sweeney, C.; Haarmann-Stemmann, T.; Matsumura, F.; Vogel, C.F.A. The aryl hydrocarbon receptor (AhR) mediates resistance to apoptosis induced in breast cancer cells. Pestic. Biochem. Physiol. 2015, 120, 5-13. [CrossRef] [PubMed]

188. Venkatesh, M.; Mukherjee, S.; Wang, H.; Li, H.; Sun, K.; Benechet, A.P.; Qiu, Z.; Maher, L.; Redinbo, M.R.; Phillips, R.S.; et al. Symbiotic bacterial metabolites regulate gastrointestinal barrier function via the xenobiotic sensor PXR and Toll-like receptor 4. Immunity 2014, 41, 296-310. [CrossRef]

189. Verma, S.; Tabb, M.M.; Blumberg, B. Activation of the steroid and xenobiotic receptor, SXR, induces apoptosis in breast cancer cells. BMC Cancer 2009, 9, 3. [CrossRef]

190. Pondugula, S.R.; Pavek, P.; Mani, S. Pregnane X Receptor and Cancer: Context-Specificity is Key. Nucl Recept. Res. 2016, 3. [CrossRef]

191. Mikó, E.; Kovács, T.; Sebő, É.; Tóth, J.; Csonka, T.; Ujlaki, G.; Sipos, A.; Szabó, J.; Méhes, G.; Bai, P. Microbiome-Microbial Metabolome-Cancer Cell Interactions in Breast Cancer-Familiar, but Unexplored. Cells 2019, 8, 293. [CrossRef]

192. Kovács, T.; Mikó, E.; Vida, A.; Sebő, É.; Toth, J.; Csonka, T.; Boratkó, A.; Ujlaki, G.; Lente, G.; Kovács, P.; et al. Cadaverine, a metabolite of the microbiome, reduces breast cancer aggressiveness through trace amino acid receptors. Sci. Rep. 2019, 9, 1300. [CrossRef] [PubMed]

193. Mikó, E.; Vida, A.; Kovács, T.; Ujlaki, G.; Trencsényi, G.; Márton, J.; Sári, Z.; Kovács, P.; Boratkó, A.; Hujber, Z.; et al. Lithocholic acid, a bacterial metabolite reduces breast cancer cell proliferation and aggressiveness. Biochim. Et Biophys. Acta. (BBA)—Bioenerg. 2018, 1859, 958-974. [CrossRef] [PubMed]

194. Kovács, P.; Csonka, T.; Kovács, T.; Sári, Z.; Ujlaki, G.; Sipos, A.; Karányi, Z.; Szeőcs, D.; Hegedús, C.; Uray, K.; et al. Lithocholic Acid, a Metabolite of the Microbiome, Increases Oxidative Stress in Breast Cancer. Cancers 2019, 11, 1255. [CrossRef] [PubMed]

195. Krishnamurthy, K.; Wang, G.; Rokhfeld, D.; Bieberich, E. Deoxycholate promotes survival of breast cancer cells by reducing the level of pro-apoptotic ceramide. Breast Cancer Res.: BCR 2008, 10, R106. [CrossRef] [PubMed] 
196. Koppel, N.; Maini Rekdal, V.; Balskus, E.P. Chemical transformation of xenobiotics by the human gut microbiota. Science 2017, 356, eaag2770. [CrossRef]

197. Ren, D.; Li, L.; Schwabacher, A.W.; Young, J.W.; Beitz, D.C. Mechanism of cholesterol reduction to coprostanol by Eubacterium coprostanoligenes ATCC 51222. Steroids 1996, 61, 33-40. [CrossRef]

198. Erdman, S.E.; Poutahidis, T. Gut bacteria and cancer. Biochim. Et Biophys. Acta. (BBA)—Rev. Cancer 2015, 1856, 86-90. [CrossRef]

199. Moss, S.F.; Blaser, M.J. Mechanisms of Disease: Inflammation and the origins of cancer. Nat. Clin. Pract. Oncol. 2005, 2, 90-97. [CrossRef]

200. Shapira, I.; Sultan, K.; Lee, A.; Taioli, E. Evolving concepts: How diet and the intestinal microbiome act as modulators of breast malignancy. ISRN Oncol. 2013, 2013, 693920. [CrossRef]

201. Letran, S.E.; Le, S.J.; Atif, S.M.; Flores-Langarica, A.; Uematsu, S.; Akira, S.; Cunningham, A.F.; McSorley, S.J. TLR5-Deficient Mice Lack Basal Inflammatory and Metabolic Defects but Exhibit Impaired CD4 T Cell Responses to a Flagellated Pathogen. J. Immunol. 2011, 186, 5406-5412.

202. Rao, V.P.; Poutahidis, T.; Fox, J.G.; Erdman, S.E. Breast Cancer: Should Gastrointestinal Bacteria Be on Our Radar Screen? Cancer Res. 2007, 67, 847-850. [CrossRef]

203. Erdman SE, P.T.; Tomczak, M.; Rogers, A.B.; Cormier, K.; Plank, B.; Horwitz, B.H.; Fox, J.G. CD4+ CD25+ regulatory $\mathrm{T}$ lymphocytes inhibit microbially induced colon cancer in Rag2-deficient mice. Am. J. Pathol. 2003, 162, 691-702. [CrossRef]

204. Jiang, X.; Shapiro, D.J. The immune system and inflammation in breast cancer. Mol. Cell. Endocrinol. 2014, 382, 673-682. [CrossRef] [PubMed]

205. Margolis, K.L.; Rodabough, R.J.; Thomson, C.A.; Lopez, A.M.; McTiernan, A.; Group, W.s.H.I.R. Prospective Study of Leukocyte Count as a Predictor of Incident Breast, Colorectal, Endometrial, and Lung Cancer and Mortality in Postmenopausal Women. JAMA Intern. Med. 2007, 167, 1837-1844. [CrossRef]

206. Azab, B.; Bhatt, V.R.; Phookan, J.; Murukutla, S.; Kohn, N.; Terjanian, T.; Widmann, W.D. Usefulness of the Neutrophil-to-Lymphocyte Ratio in Predicting Short- and Long-Term Mortality in Breast Cancer Patients. Ann. Surg. Oncol. 2012, 19, 217-224. [CrossRef] [PubMed]

207. Gritzapis, A.D.; Voutsas, I.F.; Lekka, E.; Tsavaris, N.; Missitzis, I.; Sotiropoulou, P.; Perez, S.; Papamichail, M.; Baxevanis, C.N. Identification of a Novel Immunogenic HLA-A*0201-Binding Epitope of HER-2/neu with Potent Antitumor Properties. J. Immunol. 2008, 181, 146-154. [CrossRef]

208. Franchi, L.; Warner, N.; Viani, K.; Nuñez, G. Function of Nod-like receptors in microbial recognition and host defense. Immunol. Rev. 2009, 227, 106-128. [CrossRef]

209. Roy, S.; Trinchieri, G. Microbiota: A key orchestrator of cancer therapy. Nat. Rev. Cancer 2017, $17,271$. [CrossRef]

210. Maier, I.; Berry, D.M.; Schiestl, R.H. Intestinal Microbiota Reduces Genotoxic Endpoints Induced By High-Energy Protons. Radiat. Res. 2014, 181, 45-53. [CrossRef]

211. Alexander, J.L.; Wilson, I.D.; Teare, J.; Marchesi, J.R.; Nicholson, J.K.; Kinross, J.M. Gut microbiota modulation of chemotherapy efficacy and toxicity. Nat. Rev. Gastroenterol. Hepatol. 2017, 14, 356. [CrossRef]

212. Wallace, B.D.; Roberts, A.B.; Pollet, R.M.; Ingle, J.D.; Biernat, K.A.; Pellock, S.J.; Venkatesh, M.; Guthrie, L.; O'Neal, S.K.; Robinson, S.J.; et al. Structure and Inhibition of Microbiome $\beta$-Glucuronidases Essential to the Alleviation of Cancer Drug Toxicity. Chem. Biol. 2015, 22, 1238-1249.

213. Chang, C.-W.; Liu, C.-Y.; Lee, H.-C.; Huang, Y.-H.; Li, L.-H.; Chiau, J.-S.C.; Wang, T.-E.; Chu, C.-H.; Shih, S.-C.; Tsai, T.-H.; et al. Lactobacillus casei Variety rhamnosus Probiotic Preventively Attenuates 5-Fluorouracil/Oxaliplatin-Induced Intestinal Injury in a Syngeneic Colorectal Cancer Model. Front. Microbiol. 2018, 9, 983. [CrossRef] [PubMed]

214. Mu, Q.; Tavella, V.J.; Luo, X.M. Role of Lactobacillus reuteri in Human Health and Diseases. Front. Microbiol. 2018, 9, 757. [CrossRef] [PubMed]

215. Motevaseli, E.; Dianatpour, A.; Ghafouri-Fard, S. The Role of Probiotics in Cancer Treatment: Emphasis on their In Vivo and In Vitro Anti-metastatic Effects. Int. J. Mol. Cell. Med. 2017, 6, 66-76. [PubMed]

216. Ranjbar, S.; Seyednejad, S.A.; Azimi, H.; Rezaeizadeh, H.; Rahimi, R. Emerging Roles of Probiotics in Prevention and Treatment of Breast Cancer: A Comprehensive Review of Their Therapeutic Potential. Nutr. Cancer 2019, 71, 1-12. [CrossRef]

217. Mendoza, L. Potential effect of probiotics in the treatment of breast cancer. Oncol. Rev. 2019, 13, 422. [CrossRef] 
218. Kevin, M.; Green, F.K.; Elnabawi, A.; Parveen, S.; Kwame Nyame, A.; Ishaque, A.B. Impact of Lactobacillus Reuteri DSM 20016 on breast cancer proliferation. In Proceedings of the Thirteenth International Symposium on Metal. Ions in Biology \& Medicine Eleventh International Symposium on Recent Advances in Environmental Health Research, Jackson, MS, USA, 22 July 2014.

219. Poutahidis, T.; Varian, B.J.; Levkovich, T.; Lakritz, J.R.; Mirabal, S.; Kwok, C.; Ibrahim, Y.M.; Kearney, S.M.; Chatzigiagkos, A.; Alm, E.J.; et al. Dietary microbes modulate transgenerational cancer risk. Cancer Res. 2015, 75, 1197-1204. [CrossRef]

220. Aragón, F.; Carino, S.; Perdigón, G.; de Moreno de LeBlanc, A. Inhibition of Growth and Metastasis of Breast Cancer in Mice by Milk Fermented With Lactobacillus casei CRL 431. J. Immunother. 2015, 38, 185-196. [CrossRef]

221. Hassan, Z.; Mustafa, S.; Rahim, R.A.; Isa, N.M. Anti-breast cancer effects of live, heat-killed and cytoplasmic fractions of Enterococcus faecalis and Staphylococcus hominis isolated from human breast milk. In Vitro Cell Dev. Biol. Anim. 2016, 52,337-348. [CrossRef]

222. Esfandiary, A.; Taherian-Esfahani, Z.; Abedin-Do, A.; Mirfakhraie, R.; Shirzad, M.; Ghafouri-Fard, S.; Motevaseli, E. Lactobacilli Modulate Hypoxia-Inducible Factor (HIF)-1 Regulatory Pathway in Triple Negative Breast Cancer Cell Line. Cell J. 2016, 18, 237-244.

(C) 2020 by the authors. Licensee MDPI, Basel, Switzerland. This article is an open access article distributed under the terms and conditions of the Creative Commons Attribution (CC BY) license (http://creativecommons.org/licenses/by/4.0/). 